\title{
Techno-economic modeling of an integrated biomethane-biomethanol production process via biomass gasification, electrolysis, biomethanation, and catalytic methanol synthesis
}

\author{
Lorenzo Menin $^{1}$ (D) $\cdot$ Vittoria Benedetti $^{1} \cdot$ Francesco Patuzzi $^{1} \cdot$ Marco Baratieri $^{1}$
}

Received: 7 September 2020 / Revised: 6 November 2020 / Accepted: 25 November 2020 / Published online: 10 December 2020

(C) The Author(s) 2020, corrected publication 2021

\begin{abstract}
Biological methanation (biomethanation) of syngas obtained from biomass gasification offers the opportunity to employ a lowpressure, low-temperature process to produce storable bio-derived substitute natural gas (bSNG), although its economic viability is limited by high energy and biomass costs. Research on syngas biomethanation techno-economic performance is limited and novel biomass-to-biomethane process configurations are required in order to assess opportunities for the enhancement of its efficiency and economic feasibility. In this study, we carried out the techno-economic modeling of two processes comprising integrated biomass gasification, electrolysis, and syngas biomethanation with combined heat and power recovery in order to assess and compare their fuel yields, energy efficiency, carbon efficiency, and bSNG minimum selling price (MSP). The first process operates standalone biomethanation (SAB) of syngas and can produce approximately $38,000 \mathrm{Nm}^{3}$ of bSNG per day, with a total plant efficiency of 50.6\%. The second process (integrated biomethane-biomethanol, IBB) exploits the unconverted carbon stream from the biomethanation process to recover energy and synthesize methanol via direct catalytic $\mathrm{CO}_{2}$ hydrogenation. In addition to the same bSNG output, the IBB process can produce $10 \mathrm{t} /$ day of biomethanol, at a $99 \%$ purity. The IBB process shows little global energy efficiency gains in comparison with SAB (51.7\%) due to the large increase in electrolytic hydrogen demand, but it shows a substantial improvement in biomass-to-fuel carbon efficiency ( $33 \mathrm{vs.} 26 \%$ ). The SAB and IBB processes generate a bSNG MSP of $2.38 € / \mathrm{Nm}^{3}$ and $3.68 € / \mathrm{Nm}^{3}$, respectively. Hydrogenation of unconverted carbon in biomass-to-biomethane processes comes with high additional capital and operating costs due to the large-scale electrolysis plants required. Consequently, in both processes, the market price gap of the bSNG produced is $0.13 € / \mathrm{kWh}_{\mathrm{bSNG}}$ (SAB) and $0.25 € / \mathrm{kWh}_{\mathrm{bSNG}}$ (IBB) even under the most optimistic cost scenarios considered, and it is primarily influenced by the cost of surplus electricity utilized in electrolysis, while the selling price of biomethanol exerts a very limited influence on process economics. Intensive subsidization would be required in order to sustain the decentralized production of bSNG through both processes. Despite their limited economic competitiveness, both processes have a size comparable with existing renewable gas production plants in terms of bSNG production capacity and the IBB process is of a size adequate for the supply of biomethanol to a decentralized biorenewable supply chain.
\end{abstract}

Keywords Biomethanation $\cdot$ Biomethanol $\cdot$ Power-to-gas $\cdot$ Biomass gasification $\cdot$ Techno-economic assessment

Acronyms and symbols

AD Anaerobic digestion

bSNG Bio-derived substitute natural gas

$\mathrm{bMeOH} \quad$ Biomethanol

Lorenzo Menin

1menin@unibz.it

1 Free University of Bolzano, Bolzano, Italy
CHP Combined heat and power

$C_{\text {decarb }} \quad$ Cost of grid gas decarbonization $(€ / \mathrm{kWh})$

daf Dry and ash free biomass

IBB Integrated biomethane-biomethanol

IBGEB Integrated biomass gasification-electrolysisbiomethanation

IBGM Integrated biomass gasification-methanol synthesis

$L H V_{\text {prod, } i} \quad$ Lower heating value of product $i(\mathrm{MJ} / \mathrm{kg})$ 


\begin{tabular}{|c|c|}
\hline$L H V_{\text {biom }}$ & Lower heating value of biomass $(\mathrm{MJ} / \mathrm{kg})$ \\
\hline$\dot{m}_{\text {prod }, i}$ & Mass flow rate of product $i(\mathrm{~kg} / \mathrm{s})$ \\
\hline$Q_{i}$ & Heat stream $i\left(\mathrm{MW}_{\mathrm{th}}\right)$ \\
\hline$W_{i}$ & Work stream $i\left(\mathrm{MW}_{\mathrm{el}}\right)$ \\
\hline$\dot{n}_{\mathrm{CO}, \mathrm{r} \cdot \mathrm{g} .}$ & $\begin{array}{l}\text { Molar flow rate of carbon dioxide in } \\
\text { selected reject gases }(\mathrm{mol} / \mathrm{s})\end{array}$ \\
\hline$n_{C O 2, \text { syng }}$ & $\begin{array}{l}\text { Molar flow rate of carbon dioxide in } \\
\text { treated syngas }(\mathrm{mol} / \mathrm{s})\end{array}$ \\
\hline$\dot{n}_{H 2, r . g}$ & $\begin{array}{l}\text { Molar flow rate of hydrogen in selected } \\
\text { reject gases }(\mathrm{mol} / \mathrm{s})\end{array}$ \\
\hline$n_{\mathrm{H} 2, \mathrm{elec}, \mathrm{MeOH}}$ & $\begin{array}{l}\text { Molar flow rate of hydrogen produced } \\
\text { by the electrolysis unit }(\mathrm{mol} / \mathrm{s}) \text { for } \\
\text { methanol synthesis }\end{array}$ \\
\hline$\dot{n}_{H 2, e l e c, B M}$ & $\begin{array}{l}\text { Molar flow rate of hydrogen produced } \\
\text { by the electrolysis unit }(\mathrm{mol} / \mathrm{s}) \\
\text { for biomethanation }\end{array}$ \\
\hline$\dot{v}_{B M}$ & Normal volume flow rate of biomethane \\
\hline$P_{\text {natgas }}$ & $\begin{array}{l}\text { Average market price of conventional } \\
\text { natural gas }(€ / \mathrm{kWh})\end{array}$ \\
\hline $\mathrm{PtG}$ & Power-to-gas \\
\hline PtM & Power-to-methanol \\
\hline$Q_{G B}$ & Enthalpy difference in the gasification bed \\
\hline$Q_{C B}$ & $\begin{array}{l}\text { Enthalpy difference in the char } \\
\text { combustion bed }\end{array}$ \\
\hline$Q_{\text {loss }}$ & Heat losses to the surroundings \\
\hline S-t-F & Syngas-to-fuel \\
\hline SAB & Standalone biomethanation \\
\hline SM & Stoichiometric modulus \\
\hline$T_{D H}$ & District heat stream temperature \\
\hline WGS & Water-gas shift \\
\hline
\end{tabular}

\section{Introduction}

The implementation of advanced bioeconomies relies on the efficient conversion of renewable carbon stocks into versatile fuels and chemical feedstocks. Biomass gasification has been identified as a promising technology for the thermochemical conversion of renewable biomass into a synthetic gas mixture (syngas) that can serve as a precursor to produce renewable biofuels and biochemicals [1]. Such products are the result of conversion processes operated downstream of biomass gasification and include commodities such as Fischer-Tropsch products, methanol, dimethyl ether, hydrogen, biodiesel, and biomethane in the form of bio-derived substitute natural gas (bSNG) [2]. Syngas upgrading to bSNG via methanation has attracted much attention in recent years [3], partly because of the versatility of methane as a low-emissions energy carrier that makes it a suitable fuel for the transition to a fully renewable energy system [4]. Methanation processes offer the possibility to be integrated in so-called power-to-gas ( $\mathrm{PtG}$ ) systems. In these systems, water electrolysis, powered by surplus renewable electricity, is used to produce hydrogen, which reacts with carbon dioxide to synthesize grid-quality bSNG [5], either via catalytic [6] or via biological conversion processes [7]. PtG processes offer several opportunities for future energy systems, enabling energy storage and grid stabilization while producing renewable methane [8]. Biomass gasification can thus be integrated with methanation and water electrolysis in PtG systems, with the potential to address fuel-type diversification and storage needs. Integrated biomass gasification and catalytic methanation systems have been widely studied from a modeling and system performance point of view [9], while only few studies so far have addressed the performance of integrated biomass gasification-biomethanation systems [10-12].

Among the products of syngas conversion, methanol is a fundamental platform chemical for the production of a variety of compounds in the contemporary chemical industry, such as formaldehyde, methyl tert-butyl ether, and acetic acid [13] and the production of bio-derived methanol could play an important role in future biorenewable supply chains. Methanol has also been identified as a promising transition fuel and energy carrier to lead the transportation sector towards complete decarbonization [14]. Therefore, the development of biomass-to-methanol technologies and the techno-economic analysis of related full-scale processes have recently attracted considerable attention [15]. An integrated biomass gasification-methanol synthesis (IBGM) scheme comprises biomass gasification to syngas and the subsequent catalytic synthesis of methanol via $\mathrm{CO}$ conversion to $\mathrm{CO}_{2}$ and subsequent hydrogenation (the CAMERE process), or via direct $\mathrm{CO}_{2}$ hydrogenation. Catalytic methanol synthesis from direct $\mathrm{CO}_{2}$ hydrogenation can serve as a carbon utilization process $[16,17]$ that allows the fixation of $\mathrm{CO}_{2}$ from a variety of sources into a useful product, and it can be integrated into power-to-methanol (PtM) systems, where renewable electricity is exploited to produce electrolytic hydrogen for use in methanol synthesis [18]. When large quantities of renewable hydrogen are available, $\mathrm{CO}_{2}$ hydrogenation to methanol represents an option for the valorization of renewable carbon derived from other processes via carbon utilization, according to the poly-generation needs of future bioeconomies and the biorefinery concept [19]. Moreover, the conversion of $\mathrm{CO}_{2}$ and $\mathrm{H}_{2}$ to methanol through the PtM concept allows overcoming the limitations related to the handling of pure hydrogen, by producing a versatile liquid fuel that is more easily exploitable in the existing distribution infrastructure [20]. Moioli et al. [21] demonstrated that $\mathrm{CO}_{2}$-to-methanol requires an overall lower energy input per unit mass of fuel produced than $\mathrm{CO}_{2}$ to-methane, due to the lower stoichiometric hydrogen requirements of methanol synthesis, and that it delivers a higher energy storage efficiency when normalized for electrolysis efficiencies. For this reason, $\mathrm{CO}_{2}$-to-methanol may represent a better option than $\mathrm{CO}_{2}$-to-methane when small-scale applications are considered, due to the lower investment required by smaller electrolysis sizes. 
Biological methanation (biomethanation) of biogas produced through anaerobic digestion has seen successful labscale demonstration [22-24] and pilot projects [25], and its use in PtG schemes has been investigated taking $\mathrm{AD}$ as a standalone carbon source [26] or in parallel to hydrothermal liquefaction (HTL) of digestate [27]. For standalone AD, Vo et al. [26] estimated a biomethane minimum selling price (MSP) of $1.43 € / \mathrm{Nm}^{3}$, with an electricity cost of $0.1 € / \mathrm{kWh}$. Kassem et al. [27], instead, estimated a biomethane levelized cost of energy (LCOE) of $10 \$ / \mathrm{GJ}$ (approx. $0.33 € / \mathrm{Nm}^{3}$, conversion rate $1 \mathrm{EUR}=1.1 \mathrm{USD}$ ), considering an electricity price of $0.05 \$ / \mathrm{kWh}$ and applying two US carbon pricing mechanisms on the biomethane and the biocrude produced through HTL, namely the Low Carbon Fuel Standard (LCFS) and the Renewable Fuel Standard (RFS). However, none of the two studies evaluated the effect of utilizing the available $\mathrm{CO}_{2}$ for two distinct product streams with the aid of electrolytic hydrogen.

Biomethanation of syngas has also recently been demonstrated an effective syngas-to-methane technology on the lab scale and shows potential for scale-up [28]. In a previous techno-economic assessment on an integrated biomass gasification-electrolysis-biomethanation (IBGEB) process, we identified a $\mathrm{bSNG}$ minimum selling price of $2.68 € / \mathrm{Nm}^{3}$ and we indicated that key optimization opportunities rely on lower-pressure operation and better energy integration within the process [11]. As an important advantage over catalytic methanation, syngas biomethanation offers the possibility of low-pressure $[22,23]$ or atmosphericpressure [28] operation, with the potential to generate energy savings. However, such advantage can only be exploited if the upstream process train is run at lower pressure, avoiding high-pressure units in the syngas gas conditioning section. In syngas conditioning, impurities such as $\mathrm{H}_{2} \mathrm{~S}$ and $\mathrm{NH}_{3}$ need to be removed by a combination of water scrubbing and/or catalytic reactions, and the $\mathrm{CO}_{2}: \mathrm{H}_{2}$ ratio of the feed gas needs to be lowered to avoid excessive $\mathrm{CO}_{2}$ concentration in the product $\mathrm{SNG}$, or conversely, to limit the additional hydrogen demand from electrolysis. An alternative to the use of high-pressure catalytic units for desulphurization and water-gas shift (WGS) $[29,30]$ is the simultaneous removal of $\mathrm{CO}_{2}, \mathrm{H}_{2} \mathrm{~S}$ and $\mathrm{NH}_{3}$ from syngas by combined water-methanol scrubbing [30] that can be effective at low pressures when the required reduction in concentration is limited.

Yun et al. [31] recently proposed an alternative concept to the conventional gasification-cleaning-methanation train, illustrating the use of biomass pyrolysis followed by low-temperature steam reforming of bio-oil as a promising strategy for the direct production of biomethane with high carbon conversion efficiency. The improvement of carbon efficiency in biomass-to-biomethane systems can also be addressed through the capture and utilization of carbon streams rejected by the process that could be further exploited on site to produce renewable commodities. Michailos et al. [10] have modeled carbon capture and storage (CCS) by amine scrubbing on a gasificationbiomethanation process, indicating that the system could capture $1.42 \mathrm{~kg} \mathrm{CO}_{2}$ per $\mathrm{kg}$ bSNG produced, increasing the bSNG minimum selling price (MSP) by $17 \%$ compared to a process without CCS. The authors indicated that the examined biomethanation process would only be profitable $(\mathrm{NPV}=0)$ with a price of $39 £ / t$ of $\mathrm{CO}_{2}$ captured and a penalty emission factor on fossil natural gas of $0.2 \mathrm{t} \mathrm{CO}_{2} /$ MWh. However, alternative carbon utilization options of the recovered carbon stream were not assessed in the study. Michailos et al. [12] also evaluated an integrated concept for a wastewater treatment plant comprising anaerobic digestion (AD), digestate gasification, and $\mathrm{CO}_{2}$ biomethanation, where $\mathrm{AD}$ and PEM electrolysis are the main source of $\mathrm{CO}_{2}$ and $\mathrm{H}_{2}$, respectively. In scenarios in which digestate gasification is used for the co-provision of $\mathrm{H}_{2}$ or a mixture of $\mathrm{CO}_{2}$ and $\mathrm{H}_{2}$ to biomethanation, the estimated MSP were 135 $£ / \mathrm{MWh}_{\mathrm{HHV}}$ (approx. $1.65 € / \mathrm{Nm}^{3} ; 1 \mathrm{GBP}=1.09 \mathrm{EUR}$ ) and $164 £ / \mathrm{MWh}_{\mathrm{HHV}}$ (approx. $2 € / \mathrm{Nm}^{3}$ ), respectively, with reductions of $32-42 \%$ when $\mathrm{O}_{2}$ valorization, renewable energy incentives, and grid balancing fees are included. However, the co-production of more than one fuel type was not considered in any of the layouts studied.

Further work is thus required in order to assess process integration options that can enhance the feasibility of IBGEB processes, increase their carbon efficiency, and allow for poly-generative systems that valorize waste renewable carbon. The techno-economic modeling of low-pressure biomethanation systems integrated with high-value powerto-X and carbon utilization options is required in order to assess the potential of these processes to improve the largescale feasibility of biomass-to-biomethane systems.

In this study, we implemented a techno-economic process model to assess two alternative options for the valorization of biomass carbon through the production of bSNG, biomethanol, and district heat. In a base case, we investigated the performance of an integrated biomass gasification-electrolysisbiomethanation (IBGEB) system in which low-pressure syngas conditioning is implemented via water-methanol scrubbing. In an alternative case, we assessed the performance of the same IBGEB process where the carbon stream left unconverted by the process is utilized in catalytic methanol synthesis.

The aim of the study was to verify whether carbon utilization for methanol synthesis can improve the technoeconomic performance of an IBGEB process and lower the bSNG minimum selling price. In particular, we implemented a steady-state process model in Aspen ${ }^{\circledR}$ Plus, and for each process, we estimated (1) mass balances, (2) energy balances, and (3) biomethane minimum selling price under different economic scenarios. 


\section{Materials and methods}

\subsection{Process description}

\subsubsection{Standalone biomethanation}

In standalone biomethanation (SAB), wet wood pellets are dried and converted to syngas in a $32-\mathrm{MW}_{\text {th }}$ dual-fluidized bed steam gasification plant, based on the size and configuration of the GoBiGas plant [30] (Fig. 1). Hot syngas is used to generate steam in a counter-current heat exchanger; it crosses a bag filter for the removal of particles and then transfers to the liquid scrubbing section (Fig. 2).

Particle-free syngas (SYNG-4) is cooled to $25^{\circ} \mathrm{C}$ and compressed to 5 bar, before entering a water scrubber (W$\mathrm{SCRUB}$ ) for the reduction of $\mathrm{NH}_{3}, \mathrm{H}_{2} \mathrm{~S}$, and $\mathrm{CO}_{2}$ concentration. Rich water (SPWATER) is stripped with air for the removal of the absorbed compounds and is partly recycled to the scrubber, where it is mixed with make-up water. Pre-treated syngas (SYNG-6) passes through a condenser and enters a chilled methanol scrubber (MEOHSCR) for further removal of $\mathrm{NH}_{3}, \mathrm{H}_{2} \mathrm{~S}$, and $\mathrm{CO}_{2}$. Rich methanol is depressurized (H2SSTRIP) and regenerated in a distillation column (CO2STRIP). Regenerated methanol (MEOHREG) is recycled to the scrubber inlet and mixed with fresh solvent.

Downstream of the scrubbing section (Fig. 3), treated syngas is warmed to a thermophilic temperature of $60^{\circ} \mathrm{C}$ (SYNG$11)$; it mixes with an additional hydrogen stream and enters a trickle-bed reactor for syngas bioconversion to biomethane. The produced biogas (BIOG-1), a wet mixture of $\mathrm{CH}_{4}, \mathrm{CO}_{2}$ and impurities, is dried in a condenser and is then compressed to $10 \mathrm{bar}$ and cooled to $15^{\circ} \mathrm{C}$ upstream of a pressure swing adsorption (PSA) unit for biogas purification. Purified bSNG (BIOMTN) is then injected into the gas grid at 70 bar through a multi-stage intercooled compressor (MSCOMP-1). The stoichiometric modulus (SM, Eq. (1)) represents the ratio between $\mathrm{H}_{2}$, $\mathrm{CO}$, and $\mathrm{CO}_{2}$ required to achieve full stoichiometric carbon conversion in a biomethanation system [32].

$S M=\frac{\dot{n}_{\mathrm{H}_{2}}+\dot{n}_{\mathrm{CO}}}{\dot{n}_{\mathrm{CO}_{2}}+\dot{n}_{\mathrm{CO}}}=4$

However, in order to limit the size of the electrolysis plant required, in this study, an alkaline electrolyzer supplies additional hydrogen to satisfy only a $\mathrm{H}_{2}: \mathrm{CO}_{2}$ ratio of 4 , thus leaving part of syngas carbon unconverted. The oxygen produced by the electrolysis plant is used for in-plant combustion of reject gases (CMBSTR-2, below).

Figure 4 and 5 display a representation of the energy recovery train. The mixture of reject gases (TAILS-0) is combusted at $920{ }^{\circ} \mathrm{C}$ and combustion heat is recovered by producing steam (STM-F-2) that transfers heat to the reboiler of the methanol regeneration column (heat stream Q-8, Fig. 2 ), is used to warm syngas (HX-9, Fig. 3), and finally mixes with other steam lines destined to district heat provision (not displayed). The off-gases from the reject gas combustor (CMBSTR-2) and from the char combustion bed (CMBSTR-1) are cooled to $220^{\circ} \mathrm{C}$ while transferring heat to a 50-bar steam line (STM-B-1, Fig. 5), which is subsequently expanded in a series of two turbines, first through a 35-bar pressure decrease, and then to a final pressure of 3 bar. The cooled off-gases at $220^{\circ} \mathrm{C}$ (FLUE-6) enter the biomass dryer before being ejected to the atmosphere. Further heat is recovered from the low-temperature steam exiting the turbine cycle

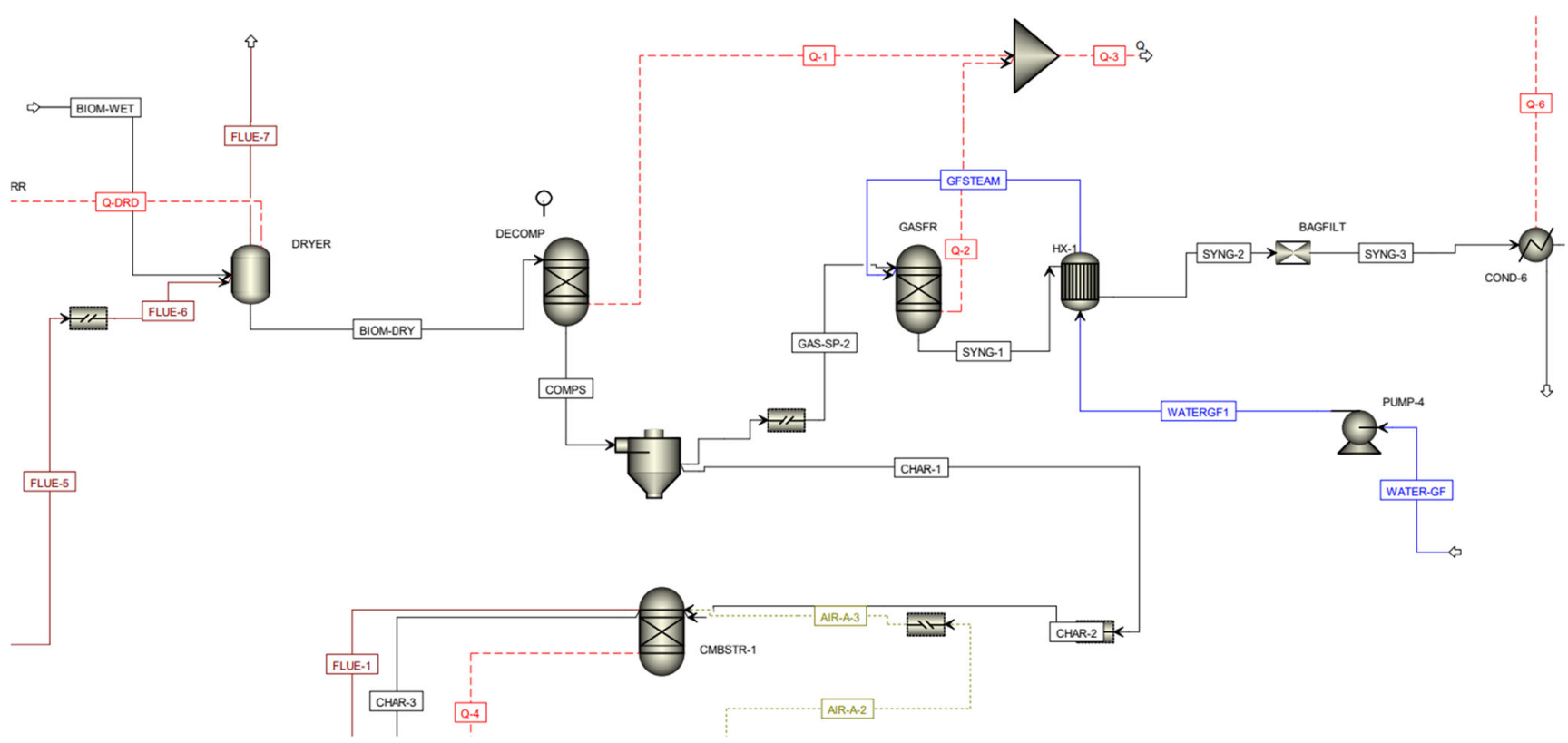

Fig. 1 Biomass drying, dual fluidized bed steam gasification, syngas cooling, particles, and moisture removal 


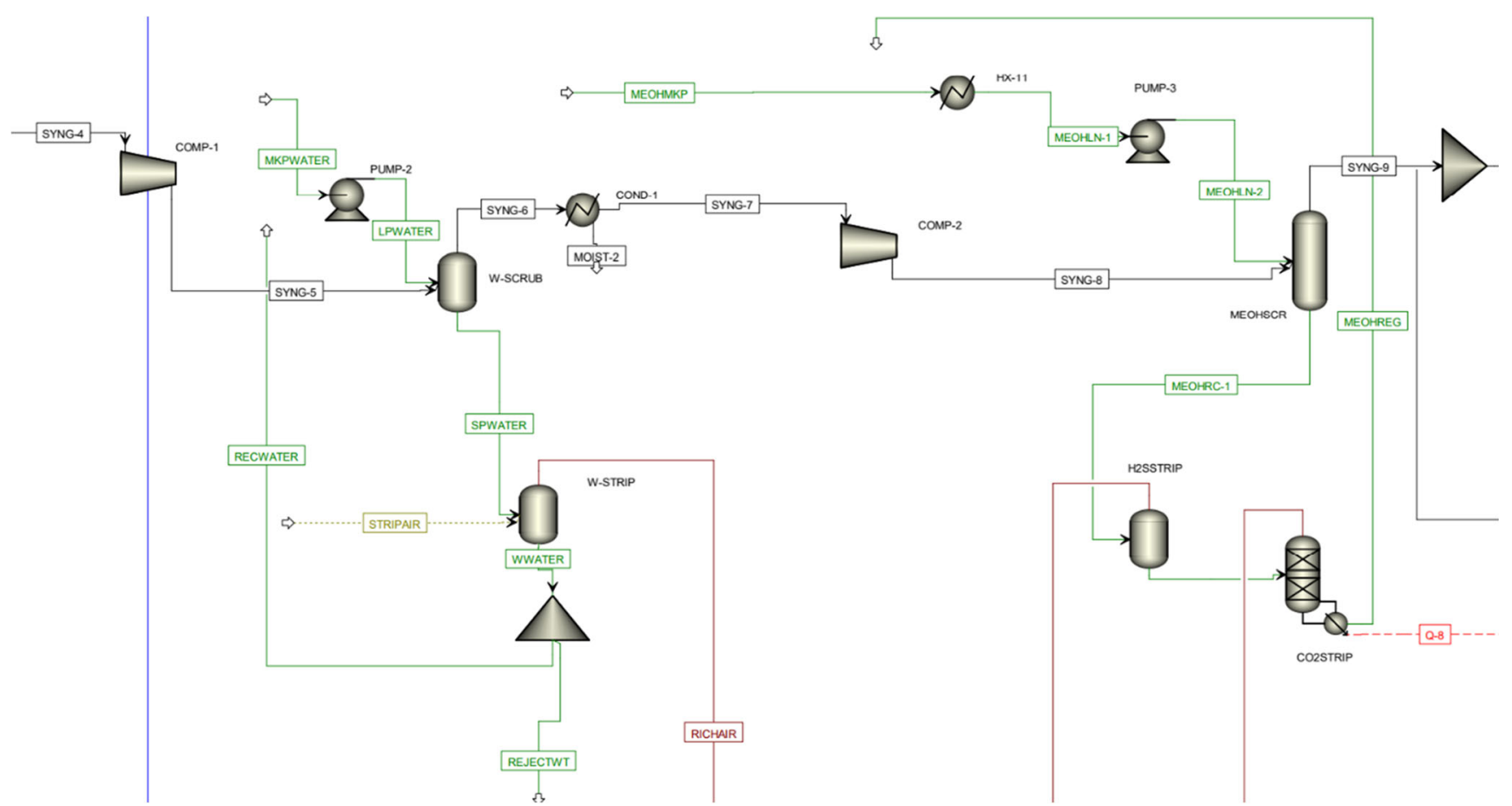

Fig. 2 Syngas water-methanol liquid scrubbing and related solvent regeneration sections

(STM-B-6) and transferred first to incoming steam (through HX-3) and secondly to the biomass dryer.

\subsubsection{Integrated biomethanol-biomethane}

In addition to the gasification, syngas conditioning, and biomethanation sections described above, in the integrated biomethanol-biomethane (IBB) process, the unconverted carbon stream rejected in biogas purification is exploited in catalytic biomethanol synthesis (Fig. 7) on a $\mathrm{Cu} / \mathrm{ZnO} / \mathrm{Al}_{2} \mathrm{O}_{3}$ catalyst [21]. Tail-gases from PSA biogas treatment are combusted (CMBSTR-3) to heat a steam line (STM-I) that supplies heat to the methanol distillation train and is then sent to district heat provision (not displayed). A mix of plant reject gases is combusted in a second combustor (CMBSTR-2) (Fig. 6), to produce another 50-bar steam line (STM-F) for expansion in the turbine cycle. A third steam line is produced by cooling the off-gases from the reject gas combustor and the

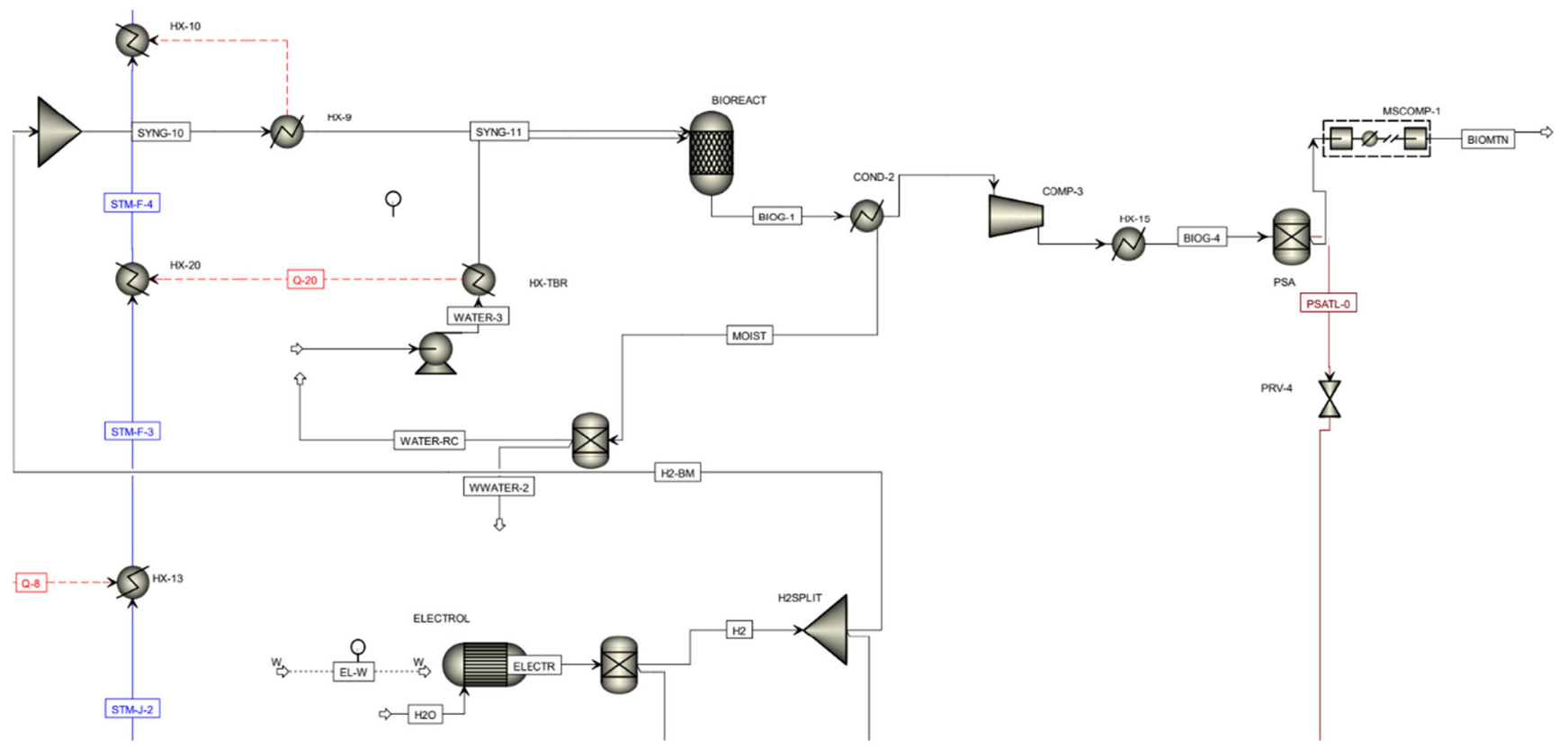

Fig. 3 Syngas biomethanation, biogas purification, and electrolysis 

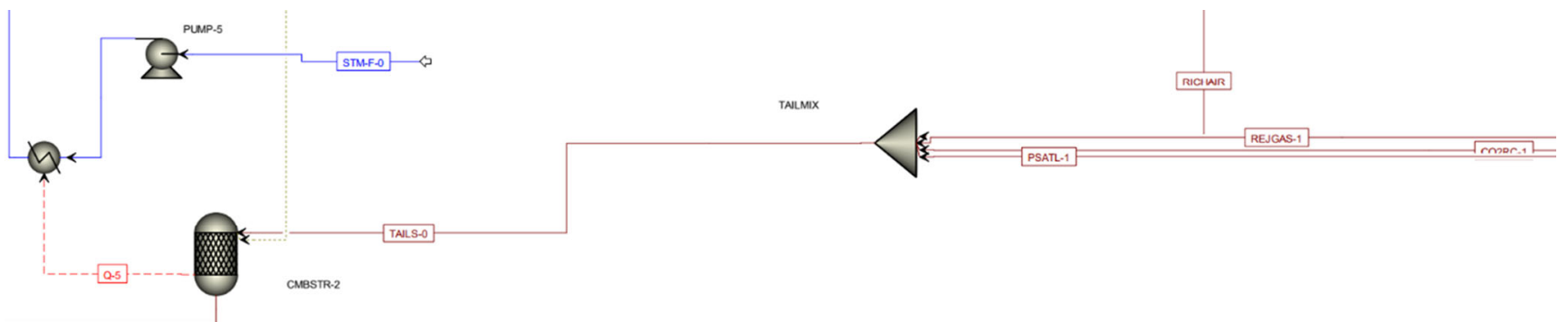

Fig. 4 Combustion of rejected plant gases for energy recovery (SAB process)

char combustion bed. The oxidized off-gases from PSA tail gas combustion (CU-1) transfer to the methanol synthesis section and mix with additional hydrogen from the electrolysis plant. The feed mixture is cooled and compressed to the reaction pressure ( $50 \mathrm{bar}$ ) in a multi-stage compressor. The reaction heat generated by $\mathrm{CO}_{2}$ hydrogenation is used to pre-heat
STM-I, while further cooling of the reaction products transfers heat to a further steam line (STM-J) for use in the biomethanation section.

The reaction products are cooled to $10^{\circ} \mathrm{C}$ and separated in a first flash drum. The liquid phase obtained is cooled and expanded in a second flash drum $\left(10^{\circ} \mathrm{C}, 1.2 \mathrm{bar}\right)$. The gas-

Fig. 5 Fuel gas cooling and steam cycle

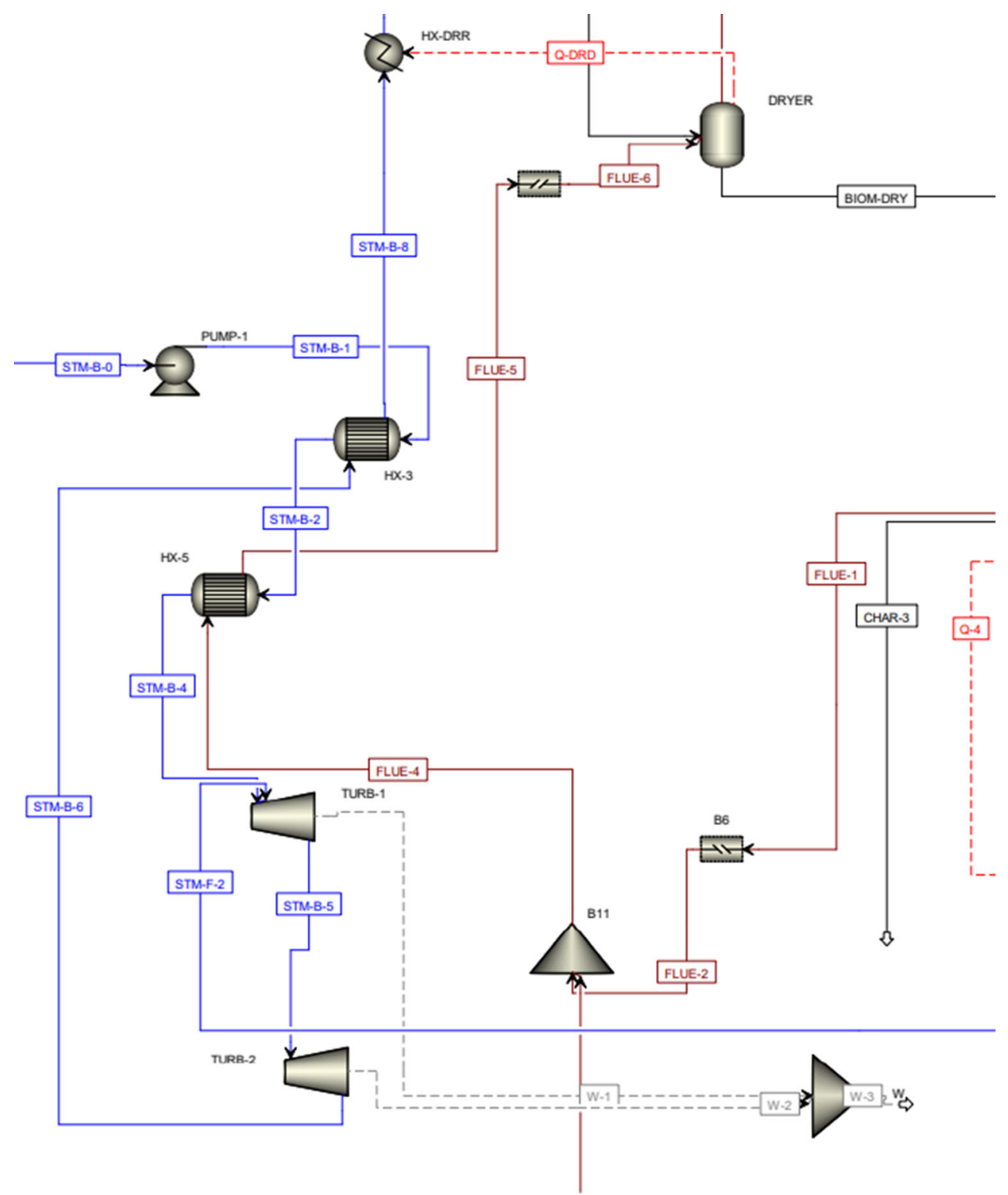




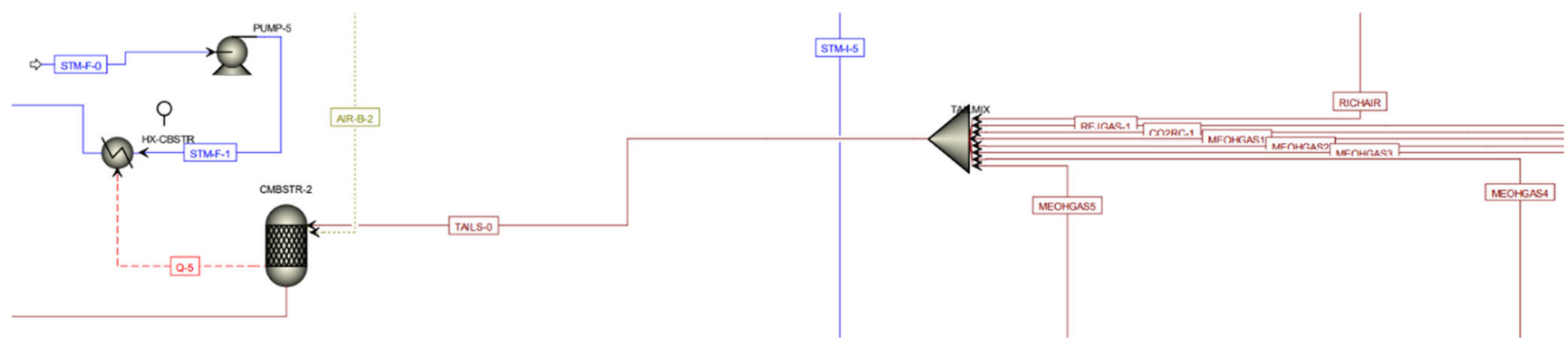

Fig. 6 Combustion of rejected plant gases for energy recovery (IBB process)

phase streams (MEOH-G-1, MEOH-G-2) are sent to combustion for energy recovery. Raw methanol (MEOH-4) is purified in a three-step distillation train, with intermediate flash gas separation and condensation units to achieve a $>99 \%$ purity in the top product of the third column. The columns reboilers exchange heat with the hot steam line STM-I, while heat is recovered from the largest wastewater stream (MEOH-5).

\subsection{Process modeling methods}

All physical, chemical, and thermal process modeling was carried out in Aspen ${ }^{\circledR}$ Plus v.10, while the evaluation of economic scenarios for the two processes was carried out in Excel ${ }^{\circledR}$. The following sections provide details on the modeling methods.

\subsubsection{Biomass steam gasification}

In the simulation of complex integrated flowsheets, biomass steam gasification has frequently been modeled by separating the pyrolysis-gasification process and the char combustion process. Under this approach, a mass and heat balance is calculated around the pyrolysis-gasification zone, the unconverted char is transferred to the combustion zone, and char combustion heat is set equivalent to the enthalpy requirements of the pyrolysis-gasification process, allowing for a fraction of heat loss [33, 34]. Some authors have simulated the pyrolysisgasification process (gasification bed) as a single-step gas formation process, either by using experimental data to reconcile a thermodynamic model $[35,36]$ or by directly implementing empirical correlations [37]. Another approach consists in subdividing the gasification bed into a biomass decomposition step and a gas formation step [10]. The DFB steam gasification process in this study was modeled according to a threestep methodology that simulates biomass decomposition, permanent gas and tar formation and char combustion. A constant biomass composition is adopted according to the experimental data reported by Alamia et al. [34]. Biomass enthalpy is estimated through the HCJ1Boje method and biomass density through the DCOALIGT method [38] that can be applied to non-conventional solid streams in Aspen Plus and RK-Aspen was selected as the thermodynamic property method used in

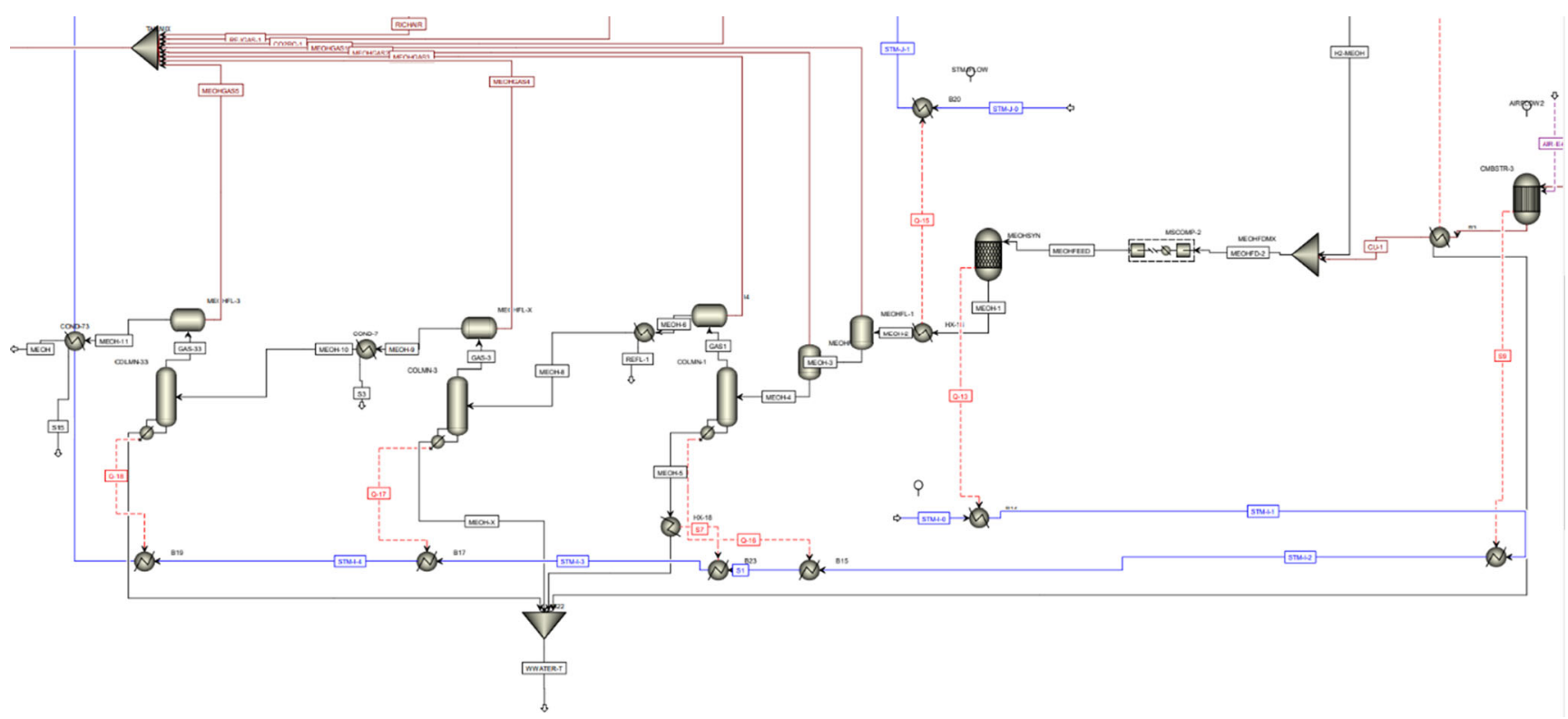

Fig. 7 Catalytic methanol synthesis and purification 
the gasification section $[37,38]$. Biomass moisture content is represented as a separate $\mathrm{H}_{2} \mathrm{O}$ stream in the mixed composition of biomass, to enable vapor-liquid flash calculations (Aspen Flash2) in the drying process. Two RYield units are used in Aspen Plus to first decompose biomass into $\mathrm{H}_{2}, \mathrm{CO}$, $\mathrm{CO}_{2}, \mathrm{CH}_{4}$, and $\mathrm{C}$ (DECOMP), according to its elemental composition, and secondly to yield the gas composition reported for the GoBiGas plant [30] (GASFR). Tar compounds were restricted to four species representing one tar class each (phenol, class 2; toluene, class 3; naphthalene, class 4; coronene, class 5). Their relative concentration and yield was adapted from Zhang and Pang [39]. The concentration of $\mathrm{H}_{2} \mathrm{~S}$ was estimated from the mass yield reported for the GoBiGas plant [34]; $\mathrm{NH}_{3}$ concentration was estimated from $\mathrm{N}$ elemental balance assuming $100 \%$ conversion to $\mathrm{NH}_{3}$, while the $\mathrm{Cl}$ biomass concentration applied $(0.006 \%)$ was considered sufficiently small to neglect any $\mathrm{HCl}$ formation in this study. Char production corresponded to a mass rate of $0.186 \mathrm{~kg}_{\text {char }} / \mathrm{kg}_{\mathrm{DB}}$ [34] and its composition was modeled as pure C (CISOLID class in Aspen Plus). Char produced in the gasification bed is separated from the products of biomass decomposition (DECOMP) with a Sep block and it is fully combusted in air at $850{ }^{\circ} \mathrm{C}$ (CMBSTR-1, RGibbs), according to a restricted thermodynamic equilibrium approach in RGibbs, where only $\mathrm{CO}_{2}, \mathrm{O}_{2}$, and $\mathrm{C}$ were set as possible products.

The model described allowed reaching a deviation of $1 \%$ on $\mathrm{C}$ atomic balance across the gasifier. Gas moisture content was then estimated by closing the $\mathrm{H}$ balance.

In a DFB gasifier, the combustion heat generated in the char bed (CMBSTR-1, Fig. 1) is transferred to the gasification bed through a solid heat transfer medium [40]. Char combustion heat (Q-4) can thus be considered equal to the enthalpy requirements of the gasification bed, while accounting for heat losses (Eq. (2)), according to a DFB concept [34, 35, 37].

$Q_{G B}=Q_{1}+Q_{2}=Q_{C B}-Q_{\text {loss }}=Q_{4}$

In this model, the enthalpy balance around the gasification bed was calculated in Aspen Plus as the algebraic sum (heat stream Q-3) of the enthalpy balances of the biomass decomposition (DECOMP, heat stream Q-1) and permanent gas formation (GASFR, heat stream Q-2) at isothermal conditions (850 $\left.{ }^{\circ} \mathrm{C}, 1 \mathrm{~atm}\right)$. Char combustion was also calculated at isothermal conditions $\left(920{ }^{\circ} \mathrm{C}, 1 \mathrm{~atm}\right.$, heat stream Q-4). The difference between heat streams Q-4 and Q-3 can be assumed to cover heat losses and is not articulated any further in this study. The DFB heat balance could thus be defined as in Eq. (3).

$Q_{4}=Q_{1}+Q_{2}+Q_{\text {loss }}=Q_{3}+Q_{\text {loss }}$

\subsubsection{Syngas conditioning and solvents regeneration}

At the gasifier outlet, syngas is cooled below $200{ }^{\circ} \mathrm{C}$ while bringing gasification steam to a temperature setpoint of $350^{\circ}$ $\mathrm{C}$ in HX-1. Subsequently, a bag filter with a $100 \%$ particle removal efficiency is simulated through a simple pressure reduction device (Valve). The water scrubber is simulated as a single-stage adiabatic flash (W-SCRUB, Flash2), while the methanol scrubbing section is modeled through a simplified adaptation of the Rectisol® process for syngas treatment [41]. The scrubbing tower is simulated by an adiabatic absorber (MEOHSCR, RadFrac) with five equilibrium stages and a chilled methanol $\left(-60^{\circ} \mathrm{C}\right.$ ) inflow rate of $2 \mathrm{~kg} / \mathrm{s}$ (solvent-tofeed rate of approximately $1.25 \mathrm{~kg}_{\mathrm{MeOH}} / \mathrm{kg}_{\text {syngas }}$ ). Stripping of rich water takes place in a single-stage adiabatic flash column (W-STRIP, Flash2). Methanol is first depressurized in a single-stage flash drum (H2SSTRIP, Flash2) at near-ambient conditions and it is then regenerated in a 10-stage distillation column (CO2STRIP, RadFrac) without condenser. The regenerated methanol stream leaves the column reboiler as a liquid at boiling point. Methanol cooling is represented through a heater block $\left(-60^{\circ} \mathrm{C}\right)$ on the incoming lean methanol stream that enters MEOHSCR. Table 1 provides a summary of the specified operating conditions for the vapor-liquid equilibrium units. All separation processes within the syngas conditioning and solvents regeneration section are simulated through vapor-liquid equilibrium (VLE) [42] according to the ELECNRTL model state equation, as recommended for acid gas absorption [43] and as previously used in the simulation of syngas scrubbing [37, 44].

\subsubsection{Biomethanation and bSNG grid injection}

Biomethanation of syngas takes place in a trickle-bed bioreactor, a reactor configuration that has been demonstrated to achieve high $\mathrm{H}_{2}$ conversion on the lab scale and shows potential for scale-up [28]. The biomethanation process is simulated through a stoichiometric reactor (BIOREACT, RStoich), where syngas is converted to biogas according to Reaction 1 and Reaction 2, at a 95\% once-through conversion efficiency on hydrogen and carbon monoxide, respectively, according to the performance of trickle-bed reactors reported by Asimakopoulos et al. [28].

Reaction 1

$\mathrm{CO}_{2}+4 \mathrm{H}_{2} \rightarrow \mathrm{CH}_{4}+2 \mathrm{H}_{2} \mathrm{O}$

Reaction 2

$4 \mathrm{CO}+2 \mathrm{H}_{2} \mathrm{O} \rightarrow \mathrm{CH}_{4}+3 \mathrm{CO}_{2}$

Liquid recirculation to the reactor is simulated through a pump, while nutrient provision modeling is not part of this 


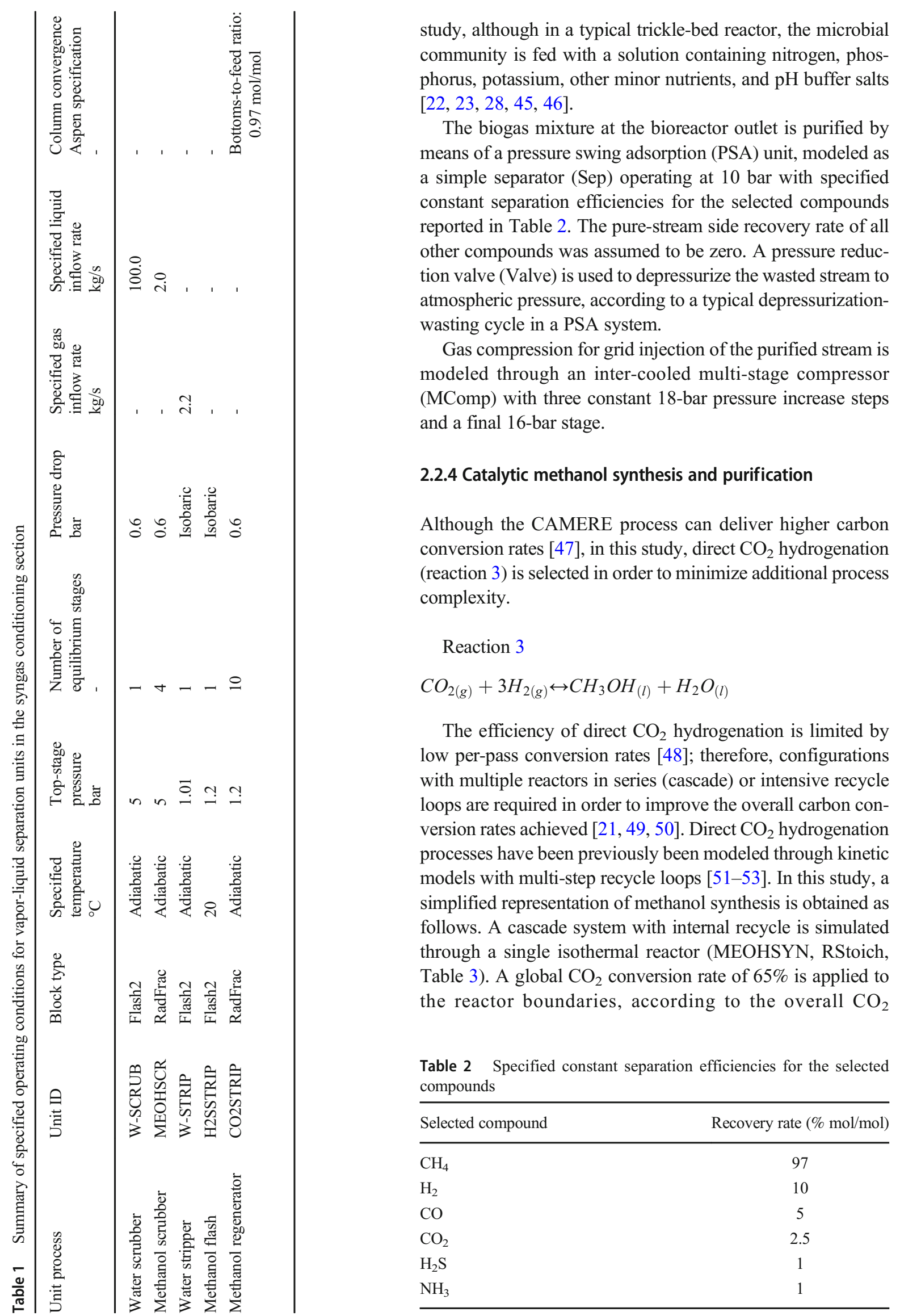


Table 3 Summary of specified process operating conditions in methanol synthesis and purification

\begin{tabular}{lllll}
\hline Unit process description & Unit ID & Block type & $\begin{array}{l}\text { Temperature } \\
{ }^{\circ} \mathrm{C}\end{array}$ & $\begin{array}{l}\text { Pressure } \\
\text { bar }\end{array}$ \\
\hline Catalytic methanol reactor & MEOHSYN & RStoich & 250 & 50 \\
Flash tanks & MEOHFL-1 & Flash2 & Adiabatic & 50 \\
& MEOHFL-2 & & 4 & 1.2 \\
& MEOHFL-3 & & 55 & 1.2 \\
& MEOHFL-4 & & 55 & 1.2 \\
Heat exchangers and condensers & MEOHFL-4 & & 65 & 1.2 \\
& HX-16 & Heater & 25 & Isobaric \\
& COND-3 & & 4 & 1.2 \\
& COND-4 & & 2 & 1.2 \\
& COND-5 & & 2 & 1.2 \\
\hline
\end{tabular}

conversion estimated by Moioli et al. [21] for a cascade configuration with optimal energy storage efficiency. Unit processes internal to the cascade configuration and recycle loops are not articulated further in this study. Table 3 provides a summary of the operating specifications applied to the simulation of methanol synthesis. The RK-Soave thermodynamic property method was used to simulate methanol synthesis and purification $[51,53,54]$.

Methanol purification is carried out via the three-step distillation process previously described (Fig. 7) and simulated by three RadFrac blocks, with specified top-stage pressures and bottoms-to-feed molar ratios (Table 4). The operating conditions of the intermediate vapor-liquid flash separation and heat exchange equipment are detailed in Table 3.

\subsubsection{Alkaline electrolysis}

Alkaline electrolysis has recently seen wide application in $\mathrm{PtG}$ projects [25] as well as the development of the first 10-MW plant worldwide in Japan $[55,56]$. Due to its mature technological development and to its durability and costcompetitiveness [57-59], alkaline electrolysis was selected as the power-to-hydrogen technology in this study. A constant efficiency of $4.4 \mathrm{kWh}$ per $\mathrm{Nm}^{3}$ of $\mathrm{H}_{2}$ output [59] was assumed and total hydrogen flow rate was calculated by a calculator block in Aspen Plus to satisfy a stoichiometric flow for Reaction 1 and Reaction 3.

\subsubsection{Energy recovery via combined cycle}

Combustion of the mixed gases takes place in an isothermal combustor (COMBSTR-2, RStoich) to generate steam as previously described. The first steam turbine decreases the steam pressure by 35 bar while the second turbine has a specified outlet pressure of 3 bar. The resultant low-pressure steam is used to pre-heat water and supply heat to the dryer, by lowering steam enthalpy (heater blocks) by an amount equivalent to the heat duty required in each unit process attached, while avoiding temperature crossovers. Heat transfer between these units is simulated via heater blocks and heat exchangers' feasibility is not articulated further. The two low-temperature steam lines are finally combined and are available for further low-temperature heat provision in a district heating system. The available heat to be exploited in district heating is estimated by cooling steam to $20{ }^{\circ} \mathrm{C}$ in a heater block (HX-DH).

\subsubsection{Efficiency indicators}

Thermal efficiency considers the fraction of biomass LHV stored as fuel LHV or exportable heat, neglecting the additional work inputs (Eq. (4)).

$\eta_{\text {th }}=\frac{\sum_{i=1}^{n} \dot{m}_{\text {prod }, i} \times L H V_{\text {prod }, i}+\sum_{i=1}^{n} Q_{i}}{\dot{m}_{d b} \times L H V_{\text {biom }}}$

Table 4 Summary of methanol distillation columns specifications

\begin{tabular}{lllll}
\hline $\begin{array}{l}\text { Unit process } \\
\text { description }\end{array}$ & ID & $\begin{array}{l}\text { Top- } \\
\text { stage } \\
\text { pressure } \\
\text { bar }\end{array}$ & $\begin{array}{l}\text { Number of } \\
\text { equilibrium stages }\end{array}$ & Bottoms-to-feed ratio \\
\hline $\begin{array}{r}\text { Distillation } \\
\text { columns }\end{array}$ & COLMN-1 & 1.2 & 10 & 0.41 \\
& COLMN-2 & 1.2 & 10 & 0.35 \\
& COLMN-3 & 1.2 & 10 & 0.05 \\
\hline
\end{tabular}


Plant efficiency (Eq (5)) considers the total LHV stored in fuels and exportable heat in relation to the total energy input into the plant, inclusive of biomass LHV and work.

$\eta_{\text {plant }}=\frac{\sum_{i=1}^{n} \dot{m}_{\text {prod }, i} \times L H V_{\text {prod }, i}+\sum_{i=1}^{n} Q_{i}}{\dot{m}_{d b} \times L H V_{\text {biom }}+\sum_{i=1}^{n} W_{i}}$

Additional information on turbomachinery efficiency, heat exchangers, and utilities usage is reported in Supplementary Material.

\subsection{Economic assessment}

\subsubsection{Capital and operating costs}

Purchased equipment costs were estimated through a factorial method by using base equipment sizes, base costs, and exponential factors retrieved from the literature (Table 5). The total heat transfer area required by the heat exchangers network in the plant was estimated through a preliminary exchanger sizing automatically estimated by the Aspen Economic Analyzer. All other equipment sizes in Table 5 could be retrieved from the plant mass and energy balance. Indirect capital costs were also estimated through the factors on direct costs indicated by Albrecht et al. [64] (Supplementary Material) and the total capital investment (TCI) was estimated according to Eq. (7).

$C=C_{0}\left(\frac{S}{S_{0}}\right)^{f}$

$C$, actual cost; $C_{0}$, base cost; $S$, actual plant size; $S_{0}$, base plant size; $f$, exponential factor.

$T C I=F C I+W C=(P E C+D C+I C+A E)+W C$

$T C I$, total capital investment; $F C I$, fixed capital investment; $W C$, working capital; $P E C$, purchased equipment cost; $D C$, direct capital cost; $I C$, indirect capital cost; $A E$, additional expenses.

Direct operating costs were calculated from the mass and energy balances obtained from the process model applying the cost rates in Table 6, while labor and indirect operating costs were estimated following the factors indicated by Albrecht et al. [64]. In particular, it was assumed that the electrolyzer works constantly at full load and that the plant operator can obtain a long-term contract in the wholesale electricity market for a fixed rate of $35 € / \mathrm{MWh}$ on power-to-gas electricity.

\subsubsection{Minimum selling price estimation}

The minimum selling price of biomethane is defined as the biomethane price that makes the project net present value (NPV) equal to zero at a given internal rate of return (IRR), according to Eq. (8).

$N P V=\sum_{i=1}^{n} \frac{C F_{n}}{(1+I R R)^{n}}=0$

By annualizing the repayment of total capital cost through an annualized capital cost term (ACC) (Eq. (9)) [65], yearly cash flow can be defined as in Eq. (10) and bSNG MSP can be calculated as in Eq. (11), applying the parameters reported in Table 7.

$A C C=F C I\left(\frac{I(1+I)^{n}}{(1+I)^{n}-1}+I(W C F)\right)$

$C F=\left(M S P_{b S N G} \times \dot{v}_{b S N G}+S R-O P E X\right)(1-t)-A C C+D E P \times t$

$M S P_{b S N G}=\left(O P E X-\left(\dot{Q}_{D H} \times P_{D H}+\dot{m}_{M e O H} \times P_{M e O H}\right)+\frac{A C C+D E P \times T}{1-T}\right) \frac{1}{\dot{v_{B M}}}$

Consequently, the difference between bSNG MSP and a base market price for a common alternative energy commodity, such as natural gas, can be estimated as in Eq. (12). Such price gap corresponds to the cost of achieving grid gas renewability through biomass-to-biomethane technologies.

$P_{g}=M S P_{b S N G}-P_{\text {natgas }}$

\subsubsection{Sensitivity analysis on major direct OPEX assumptions}

It was previously demonstrated that biomass and surplus electricity cost have a strong impact on the MSP of bSNGproduced biomass-to-biomethane processes [10,11]. Consequently, these OPEX sources, as well as the selling price of biomethanol as a side product in IBB, are expected 
Table 5 Summary of purchased equipment cost estimates

\begin{tabular}{|c|c|c|c|c|c|c|c|c|}
\hline & $S_{0}$ & $S$ & Unit & $\mathrm{C}_{0}(\mathrm{M} €)$ & Year & $f$ & $C(\mathrm{M} €)$ & Reference \\
\hline \multicolumn{9}{|l|}{ Gasification island } \\
\hline Gasifier & 32 & 33.30 & $\mathrm{MW}_{\text {th }}$ & 11.00 & 2011 & 0.8 & 11.36 & {$[30]$} \\
\hline $\begin{array}{l}\text { Biomass storage, preparation, } \\
\text { feeding to atmospheric pressure }\end{array}$ & 64.6 & 7.09 & $\mathrm{t}_{\mathrm{wet}} / \mathrm{h}$ & 1.83 & 2000 & 0.77 & 0.37 & {$[60]$} \\
\hline Air drier & 0 & 16.42 & 0 & 0.00 & 2003 & 0 & 0.00 & {$[60]$} \\
\hline \multicolumn{9}{|l|}{ Cleaning section } \\
\hline Fabric filter & 15.6 & 4.85 & $\mathrm{~m}^{3} / \mathrm{s}$ & 0.06 & 2002 & 0.77 & 0.03 & {$[60]$} \\
\hline Water scrubber & 12.1 & 0.02 & $\mathrm{~m}^{3} / \mathrm{s}$ & 2.70 & 2002 & 0.7 & 0.03 & {$[60]$} \\
\hline Water stripper & 24,123 & 380.21 & $\mathrm{kmol} / \mathrm{h}$ & 3.60 & 2009 & 0.7 & 0.22 & {$[61]$} \\
\hline Methanol scrubber & 6021.1 & 215.95 & $\mathrm{kmol} / \mathrm{h}$ & 8.81 & 2007 & 0.63 & 1.20 & {$[62]$} \\
\hline $\mathrm{CO}_{2}$ desorption & 6021.1 & 215.95 & $\mathrm{kmol} / \mathrm{h}$ & 2.10 & 2007 & 0.63 & 0.29 & {$[62]$} \\
\hline Methanol regeneration column & 6021.1 & 215.95 & $\mathrm{kmol} / \mathrm{h}$ & 1.08 & 2007 & 0.67 & 0.13 & {$[62]$} \\
\hline \multicolumn{9}{|l|}{ Biomethanation section } \\
\hline Bioreactor & 5 & 15.68 & $\mathrm{MW}_{\mathrm{LHV}}$ & 2.46 & 2016 & 0.6 & 4.89 & {$[26]$} \\
\hline PSA & 1 & 1582.42 & $\mathrm{Nm}^{3} / \mathrm{h}$ & 0.00 & 2018 & 0.7 & 0.78 & {$[63]$} \\
\hline \multicolumn{9}{|c|}{ Biomethanol synthesis and purification } \\
\hline Catalytic reactor & 5000 & 226.38 & $\mathrm{t} / \mathrm{d}$ & 61.60 & 2005 & 0.67 & 7.74 & {$[47]$} \\
\hline Distillation system & 5292 & 226.38 & $\mathrm{t} / \mathrm{d}$ & 14.40 & 2008 & 0.67 & 1.74 & {$[47]$} \\
\hline \multicolumn{9}{|l|}{ Steam cycle - energy recovery } \\
\hline Combustor & 20 & 7.84 & $\mathrm{MW}_{\mathrm{LHV}}$ & 1.97 & 2014 & 0.83 & 0.91 & {$[64]$} \\
\hline Turbine cycle & 25 & 1.28 & $\mathrm{MW}_{\text {output }}$ & 8.47 & 2014 & 0.7 & 1.06 & {$[64]$} \\
\hline \multicolumn{9}{|l|}{ Electrolysis } \\
\hline Electrolyzer & 1 & 24.47 & $\mathrm{MW}_{\text {installed }}$ & 0.64 & 2014 & 1 & 15.66 & {$[64]$} \\
\hline \multicolumn{9}{|l|}{ Secondary equipment } \\
\hline $\begin{array}{l}\text { Compressors } \\
\text { Pumps }\end{array}$ & $\begin{array}{l}413 \\
10\end{array}$ & $\begin{array}{l}2932.16 \\
0.03\end{array}$ & $\begin{array}{l}\mathrm{kW}_{\text {input }} \\
\mathrm{m}^{3} / \mathrm{s}\end{array}$ & $\begin{array}{l}0.49 \\
0.10\end{array}$ & $\begin{array}{l}2014 \\
2014\end{array}$ & $\begin{array}{l}0.68 \\
0.36\end{array}$ & $\begin{array}{l}1.86 \\
0.01\end{array}$ & {$[64]$} \\
\hline Heat exchangers & 1000 & 2596.24 & $\mathrm{~m}^{2}$ & 0.26 & 2014 & 1 & 0.68 & \\
\hline Refrigeration system & 500 & 1149.28 & $\mathrm{~kW}_{\text {input }}$ & 1.06 & 2014 & 0.68 & 1.87 & \\
\hline
\end{tabular}

to show an important impact on bSNG price gap (Eq. (12)). Therefore, the effect of their variation from the base-case values used in the main process simulations needs to be assessed. For these reasons, a two-parameter sensitivity analysis was carried out on bSNG price gap, by assessing the variation of surplus $(\mathrm{PtG})$ electricity cost and biomass cost for the $\mathrm{SAB}$ process, and the variation of $\mathrm{PtG}$ electricity cost

Table 6 Summary of main direct operating cost items

\begin{tabular}{lll}
\hline Item & Cost $(€)$ & Unit \\
\hline Labor & 24.00 & man-hour \\
Biomass & 100.00 & $\mathrm{t}$ dry \\
Electricity & 90.00 & $\mathrm{MWh}$ \\
Power-to-gas electricity & 35.00 & $\mathrm{MWh}$ \\
Water & 2.00 & $\mathrm{~m}^{3}$ \\
Catalyst & 56.80 & $\mathrm{~m}^{3} \mathrm{MeOH}$ output \\
Wastewater management & 2.50 & $\mathrm{~m}^{3}$ \\
\hline
\end{tabular}

and biomethanol selling price for the IBB process at a basecase biomass cost of $100 € / t_{\text {dry }}$ (Table 8 ). An average market price of $0.03 € / \mathrm{kWh}$ for grid natural gas was employed in the renewability cost estimation, based on EU28 statistics [70].

Table 7 Summary of project information

\begin{tabular}{llll}
\hline Item & Symbol & Value & Unit \\
\hline Project lifetime & $n$ & 15 & Years \\
Interest rate & $I$ & $10 \%$ & - \\
Tax rate & $t$ & $35 \%$ & - \\
Biomethanol selling price $^{\mathrm{a}}$ & $P_{M e O H}$ & 275 & $€ / \mathrm{t}$ \\
District heat selling price $^{\mathrm{b}}$ & $P_{D H}$ & 0.07 & $€ / \mathrm{kWh}$ \\
\hline
\end{tabular}

${ }^{a}$ Price published by a commercial operator for fossil methanol for the European market [66]. No renewable energy price incentives were assumed

${ }^{\mathrm{b}}$ Typical average price for residential district heat for small consumers in the Northern Italian region [67-69] 
Table 8 Summary of parameter variations in the sensitivity analysis on OPEX assumptions

\begin{tabular}{llllllll}
\hline Parameter & Symbol & Unit & Lower bound & Base case & Upper bound & Parameter status \\
\cline { 3 - 7 } & & & & & & SAB & IBB \\
\hline PtG electricity cost & $C_{P t G}$ & $€ / M W h$ & $0(-100 \%)$ & 35 & $105(+200 \%)$ & Variable & Variable \\
Biomass cost & $C_{\text {biom }}$ & $€ / t_{\text {dry }}$ & $0(-100 \%)$ & 100 & $200(+100 \%)$ & Variable & Constant at base case \\
Biomethanol selling price & $P_{b M e O H}$ & $€ / t$ & $0(-100 \%)$ & 275 & $619(+125 \%)$ & Absent & Variable \\
\hline
\end{tabular}

\section{Results}

\subsection{Process mass and energy balance}

Table 9 and Table 10 report a summary of selected process streams for the SAB and IBB processes, respectively.

As shown in Table 11, the standalone biomethane (SAB) process can produce $37,978 \mathrm{Nm}^{3} /$ day of grid-injected biomethane, with a volumetric yield on biomass of 0.24 $\mathrm{Nm}^{3}{ }_{\mathrm{BM}} / \mathrm{kg}_{\mathrm{DB}}$ and a corresponding plant efficiency of $47 \%$ on biomass thermal input (Table 12). The SAB process delivers 6.3 MW of district heat available at $100{ }^{\circ} \mathrm{C}$ (Fig. 8). In addition to the same biomethane output, the integrated biomethane-biomethanol (IBB) process can produce $10 \mathrm{t} /$ day of biomethanol with a $99 \%$ purity at a mass yield of 0.09 $\mathrm{kg}_{\mathrm{MEOH}} / \mathrm{kg}_{\mathrm{DB}}$. As a result of heat integration, the IBB process also delivers 11.9 MW of district heat (Fig. 9).

Table 11 also displays the biomass-to-fuel (B-t-F) and syngas-to-fuel (S-t-F) carbon efficiency of the two alternatives, indicating that IBB brings substantial advantages in terms of carbon efficiency, storing an additional carbon stream equivalent to $7281 \mathrm{t} / \mathrm{y}$ of $\mathrm{CO}_{2}$ as pure methanol. Consequently, the global B-t-F efficiency of the IBB process is $27 \%$ higher than in $\mathrm{SAB}$, demonstrating that despite the increase in plant size and complexity, bSNG production with carbon utilization could play an important role as a carbon management strategy. Equally, S-t-F efficiency is higher in IBB $(42 \%)$ than in SAB (33\%). The greatest carbon loss in $\mathrm{SAB}$ is related to the absence of $\mathrm{CO}_{2}$ utilization and the complete rejection of off gases. The IBB scenario still presents major losses other than flue gases from combustion. These include especially rejected carbon streams in methanol purification, such as wastewater, with an overall methanol recovery of $82 \%$ across the distillation train.

The estimated biomethanol yield on $\mathrm{CO}_{2}$ is 0.47 $\mathrm{kg}_{\mathrm{MeOH}} / \mathrm{kg}_{\mathrm{CO} 2}$ upstream of distillation and 0.31 $\mathrm{kg}_{\mathrm{MeOH}} / \mathrm{kg}_{\mathrm{CO} 2}$ considering pure product output, which is similar to the yield estimated by Crivellari et al. [52] (0.36 $\mathrm{kg}_{\mathrm{MeOH}} / \mathrm{kg}_{\mathrm{CO} 2}$ ) in the thermoeconomic modeling of methanol production from surplus wind energy. The estimated yield, however, is lower than reported in most previous studies on direct $\mathrm{CO}_{2}$ hydrogenation to methanol, probably due to the absence of intensive recycling loops in study, where combustion of unconverted gases is preferred over complex recycling infrastructure. In particular, the estimated yield is $53 \%$ lower than estimated by Van-Dal and Bouallou [51] and by

Table 9 Summary of selected process streams for the SAB process

\begin{tabular}{|c|c|c|c|c|c|c|c|c|c|}
\hline \multicolumn{10}{|l|}{ Stream ID } \\
\hline Parameter & Unit & SYNG-1 & MEOHREG & CO2RC-1 & SYNG-11 & BIOG-2 & BIOMTN & TAILS-0 & FLUE-7 \\
\hline Temperature & $\mathrm{C}$ & 815.0 & 80.0 & 61.9 & 60.0 & 5.0 & 35.0 & 21.8 & 120.0 \\
\hline Pressure & bar & 1.0 & 1.8 & 1.2 & 1.0 & 4.0 & 79.6 & 1.0 & 1.0 \\
\hline Total mole flow & $\mathrm{kmol} /$ day & 9125.1 & 5214.3 & 161.3 & 7207.4 & 2929.5 & 1726.1 & 8717.3 & $10,847.0$ \\
\hline Mole fractions & & 5.07 & 0.00 & 0.26 & 5.69 & 58.99 & 97.11 & 1.20 & 0.00 \\
\hline $\mathrm{CH}_{4}$ & & 19.59 & 0.00 & 0.00 & 62.48 & 7.69 & 1.30 & 2.33 & 0.00 \\
\hline $\mathrm{H}_{2}$ & & 11.95 & 0.00 & 0.07 & 14.53 & 1.79 & 0.15 & 1.07 & 0.00 \\
\hline $\mathrm{CO}$ & & 18.02 & 0.00 & 20.22 & 15.62 & 27.39 & 1.16 & 14.92 & 25.68 \\
\hline $\mathrm{CO}_{2}$ & & 41.36 & 0.01 & 0.00 & 0.00 & 0.00 & 0.01 & 2.18 & 20.07 \\
\hline $\mathrm{H}_{2} \mathrm{O}$ & $\%$ & 0.00 & 0.00 & 0.00 & 0.00 & 0.00 & 0.00 & 58.47 & 46.99 \\
\hline $\mathrm{C}_{2} \mathrm{H}_{2}$ & & 0.07 & 0.00 & 0.37 & 0.05 & 0.12 & 0.00 & 0.07 & 0.00 \\
\hline $\mathrm{C}_{2} \mathrm{H}_{4}$ & & 1.53 & 0.00 & 0.93 & 1.39 & 3.41 & 0.00 & 1.60 & 0.00 \\
\hline $\mathrm{CH}_{3} \mathrm{OH}$ & & 0.00 & 99.54 & 75.44 & 0.06 & 0.16 & 0.27 & 2.27 & 0.00 \\
\hline $\mathrm{H}_{2} \mathrm{~S}$ & $\mathrm{ppm}_{\mathrm{mol}}$ & 106.4 & 0.0 & 1133.7 & 17.0 & 41.9 & 0.7 & 111.2 & 0.0 \\
\hline $\mathrm{NH}_{3}$ & & 567.3 & 0.0 & $22,834.5$ & 1.4 & 3.4 & 0.1 & 591.7 & 0.0 \\
\hline
\end{tabular}


गิ

$\frac{i}{m} \stackrel{i}{\frac{1}{m}}$

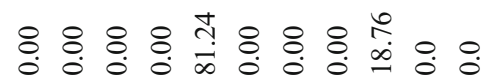

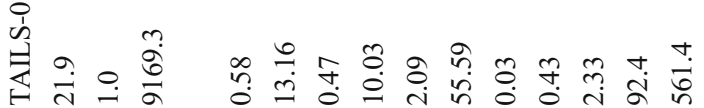

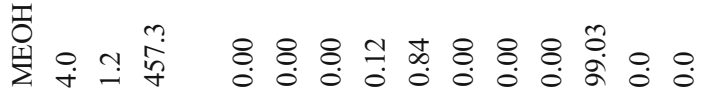

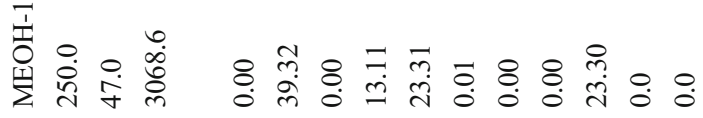

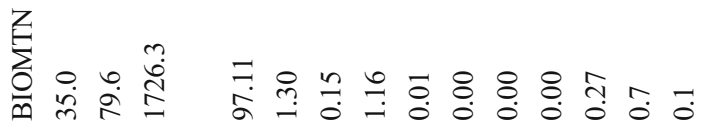

颀

矛

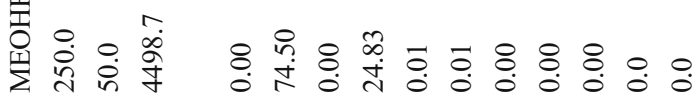

苟

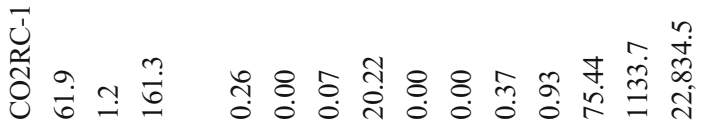

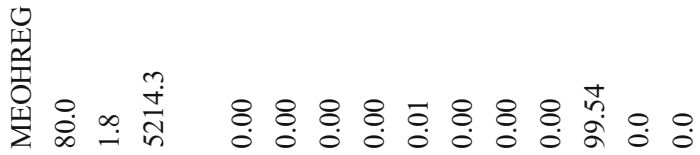

矛范

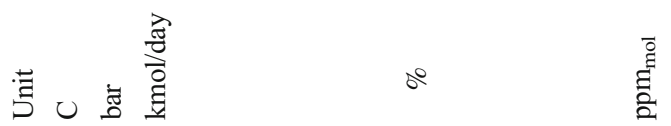

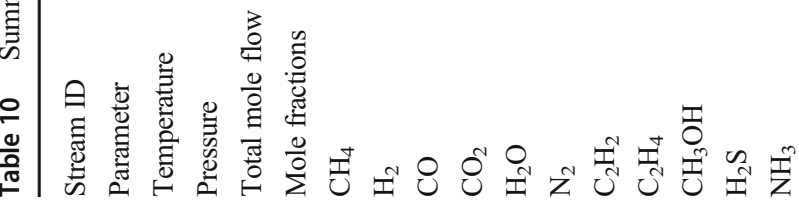


Table 11 Summary of process mass balance and efficiency indicators

\begin{tabular}{|c|c|c|c|}
\hline \multirow[t]{2}{*}{ Indicator } & \multirow[t]{2}{*}{ Unit } & \multicolumn{2}{|l|}{ Process } \\
\hline & & SAB & IBB \\
\hline \multicolumn{4}{|l|}{ Product output } \\
\hline Biomethane & $\mathrm{Nm}^{3} /$ day & 37,978 & 37,975 \\
\hline Biomethanol & t/day & - & 10 \\
\hline \multicolumn{4}{|l|}{ Product yield } \\
\hline Biomethane & $\mathrm{Nm}^{3} / \mathrm{kg}_{\mathrm{DB}}$ & 0.24 & 0.24 \\
\hline Biomethanol & $\mathrm{kg} / \mathrm{kg}_{\mathrm{DB}}$ & - & 0.09 \\
\hline \multicolumn{4}{|l|}{ Carbon efficiency } \\
\hline Biomass-to-fuel & $\mathrm{mol} \mathrm{C}_{\text {fuel }} / \mathrm{mol} \mathrm{C}_{\mathrm{db}}$ & $26 \%$ & $33 \%$ \\
\hline Syngas-to-fuel & $\mathrm{mol} \mathrm{C}_{\text {fuel }} / \mathrm{mol} \mathrm{C}_{\text {syng }}$ & $33 \%$ & $41 \%$ \\
\hline Carbon dioxide utilized & t/year & - & 7281 \\
\hline \multicolumn{4}{|l|}{ bSNG specific work input } \\
\hline Total & $\mathrm{kWh}_{\mathrm{el}} / \mathrm{Nm}_{\mathrm{bSNG}}^{3}$ & 7.65 & 17.01 \\
\hline Before electrolysis & $\mathrm{kWh}_{\mathrm{el}} / \mathrm{Nm}^{3}{ }_{\text {bSNG }}$ & 0.73 & 1.54 \\
\hline
\end{tabular}

Alsayegh [71] $\left(0.67 \mathrm{~kg}_{\mathrm{MeOH}} / \mathrm{kg}_{\mathrm{CO} 2}\right)$ for a direct $\mathrm{CO}_{2}$ hydrogenation process through a kinetic model in Aspen Plus. Pérez-Fortes et al. [72] estimated a $0.68 \mathrm{~kg}_{\mathrm{MeOH}} / \mathrm{kg}_{\mathrm{CO} 2}$ from an adaptation of the same process, while Anicic et al. [47] estimated a $0.65 \mathrm{~kg}_{\mathrm{MeOH}} / \mathrm{kg}_{\mathrm{CO} 2}$ yield for a $\mathrm{CO}_{2}$-to-methanol process modeled with two reactors in series and gas recycle at a constant single-pass conversion efficiency of $21 \%$.

Figure 8 and 9 display a summary of the main energy streams in the two processes, indicating that the plant thermal efficiency in the IBB option is $26 \%$ higher than in SAB (82.9 vs. $66.1 \%$ ) (Table 12). However, the global plant efficiencies are practically similar (50.6\% and $51.7 \%$ ), indicating that the additional energy stream required by intensive hydrogen supply in IBB is stored at a comparable rate with the SAB process, although a larger share of total energy input is recovered as lower-quality district heat in IBB, rather than as storable fuel. Only $24.9 \%$ and $5.8 \%$ of total energy input is stored as methane and methanol, respectively, in the IBB process. This indicates that the lower hydrogen conversion efficiency in methanol synthesis, compared with methane biosynthesis, limits the overall efficiency of the integrated process from an energy efficiency point of view. However, a sole energetic evaluation of the two systems does not highlight the benefits of producing methanol as a chemical feedstock for local supply chains and a chemical exergy assessment would provide more representative comparisons. The net exportable thermal energy stream generated by both plants is district heat available at $100{ }^{\circ} \mathrm{C}(6.3$ and $11.9 \mathrm{MW}$ for SAB and IBB, respectively). The combined steam cycle also yields $0.98 \mathrm{MW}$ and 1.28 MW of electricity, which serves for parasitic consumption in both scenarios.

The two processes require no direct thermal inputs other than biomass, while electrical consumption is largely dominated by electrolysis in both cases (90\% in SAB and $91 \%$ in IBB), as a result of the absence of any WGS unit. The resulting specific energy input for bSNG is $7.65 \mathrm{kWh} /$ $\mathrm{Nm}^{3}{ }_{\mathrm{bSNG}}$ for $\mathrm{SAB}$, compared to $2.3 \mathrm{kWh} / \mathrm{Nm}^{3}{ }_{\mathrm{bSNG}}$ for an IBGEB process with WGS [11]. This indicates that entirely avoiding catalytic WGS largely increases electrolytic hydrogen demand and consequently the specific energy demand of the renewable biomethane produced. Neglecting electrolysis, however, the specific work input in this study is $0.73 \mathrm{kWh} /$ $\mathrm{Nm}^{3}{ }_{\mathrm{bSNG}}$, compared to approximately $2 \mathrm{kWh} / \mathrm{Nm}^{3}{ }_{\mathrm{bSNG}}$ in our previous study [11] and approximately $1.5 \mathrm{kWh} / \mathrm{Nm}^{3}{ }_{\mathrm{bSNG}}$ for an integrated gasification-biomethanation process without electrolysis [10]. The specific energy input for the IBB process is $17 \mathrm{kWh} / \mathrm{Nm}^{3}$, although this includes the production of methanol. Gas compression includes bSNG injection into the grid (70 bar) and raising of gas pressure to 50 bar in methanol synthesis (IBB only), but it only accounts for 5.3\% of total electrical consumption in $\mathrm{SAB}$ and $6 \%$ in IBB. Compression energy requirements in the $\mathrm{SAB}$ process amount to $0.41 \mathrm{kWh} /$ $\mathrm{Nm}^{3}{ }_{\text {bSNG }}$ and compare to $0.98 \mathrm{kWh} / \mathrm{Nm}^{3}{ }_{\text {bSNG }}$ estimated in our previous assessment of a biomass-to-biomethane process including catalytic WGS at 15 bar (a) [11]. Such results suggest that using low-pressure syngas conditioning processes to increase the syngas stoichiometric modulus by extracting $\mathrm{CO}_{2}$ is more beneficial than hydrogen-generating reforming processes run at higher pressures, when considering specific energy consumption before electrolysis, and they deliver a syngas quality compatible with biomethanation [73]. Therefore, low-pressure liquid scrubbing is an energetically favorable alternative to catalytic syngas conditioning in IGBEB processes, when large quantities of surplus renewable electricity are available and surplus high-temperature heat is unavailable.

\subsection{Process economics}

Table 13 displays a summary of project economic indicators for each process configuration, including purchased
Table 12 Summary of process energy balance

\begin{tabular}{lllll}
\hline Process ID & Thermal efficiency & Plant efficiency & $\begin{array}{l}\text { bSNG specific } \\
\text { energy input } \\
\mathrm{kWh} / \mathrm{Nm}^{3}\end{array}$ & $\begin{array}{l}\text { bSNG specific energy input } \\
\text { before electrolysis } \\
\mathrm{kWh} / \mathrm{Nm}^{3}\end{array}$ \\
\hline SAB & 66.1 & 50.6 & 7.65 & 0.73 \\
IBB & 89.8 & 51.5 & 17.01 & 1.54 \\
\hline
\end{tabular}


Fig. 8 Sankey diagram of energy flows (MW) in the SAB process.

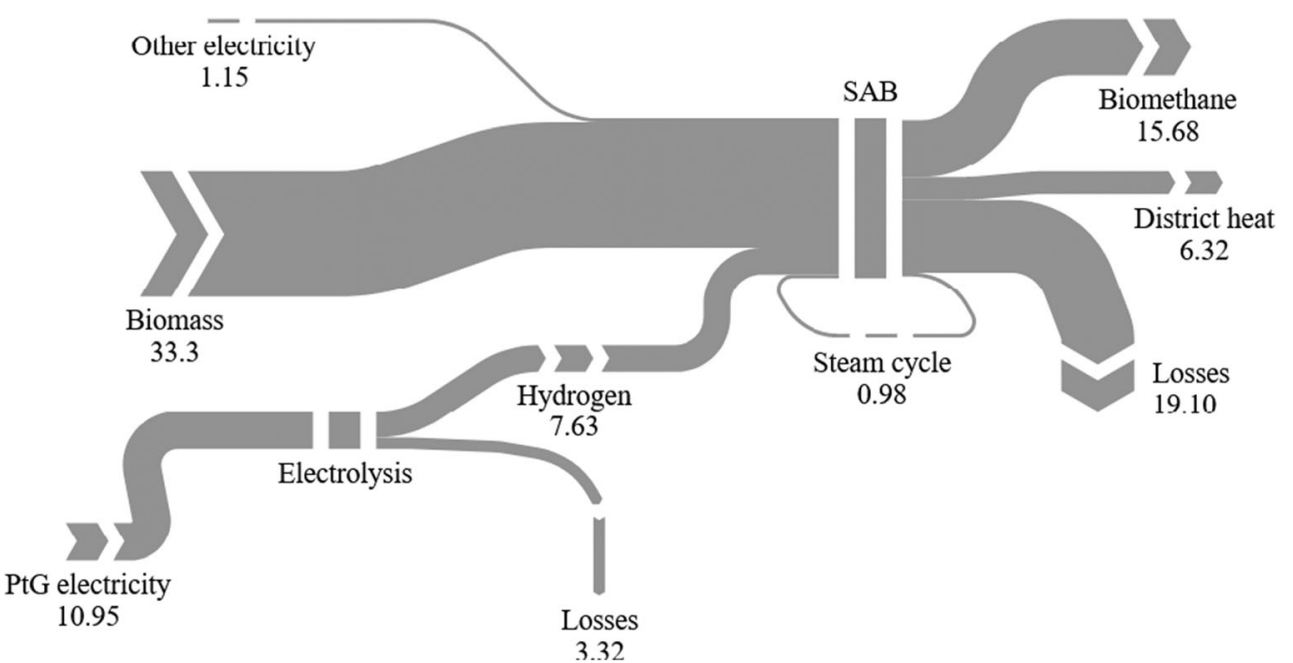

equipment cost (PEC), total capital investment (TCI), direct yearly operating cost (D-OPEX), and total yearly operating cost (T-OPEX).

Figure 10 displays the breakdown of purchased equipment costs (PEC) for the two processes, indicating that large-scale electrolysis dominates the investment costs for the IBB process $(37 \%)$, while it is the second PEC contributor (23\%) in $\mathrm{SAB}$, after gasification (39\%). The size of the electrolysis plant in the SAB process is $11 \mathrm{MW}$, which is comparable with the size of the currently largest alkaline electrolysis (AE) plant worldwide $[55,56]$, suggesting that the operation of a similar system would be possible at the present technological readiness of AE. The electrolysis throughput required in the IBB process, instead, is approximately $24 \mathrm{MW}$, which would still represent a very large size plant, with limited feasibility. The next most capital-intensive plant section is biomethanation in both processes, while biomethanol synthesis and purification only contribute to $4 \%$ of PEC in the IBB process, indicating that the greatest CAPEX barrier of a process with carbon utilization is represented by large-scale electrolysis.

Figure 11 displays the breakdown of direct operating costs for the two processes. Biomass represents the greatest cost share in SAB (58\%) and the second largest contributor $(36 \%)$ in IBB, while PtG electricity is the largest OPEX component in IBB (48\%) and the second largest component in SAB (34\%). This highlights how the cost of electricity and biomass are the fundamental bottlenecks to the feasibility of IBGEB processes, as we previously demonstrated [11]. The role attributed to electrolysis is in line with various studies that recently identified it as the main CAPEX and OPEX contributor in similar process concepts, comprising $\mathrm{CO}_{2}$-to-methane [74, 75], $\mathrm{CO}_{2}$-to-methanol [76, 77], and $\mathrm{CO}_{2}$-to-DME [78], although the same pattern has also been recognized across all the electrofuels mentioned and for electro-diesel and electrogasoline [79].
Fig. 9 Sankey diagram of energy flows (MW) in the IBB process

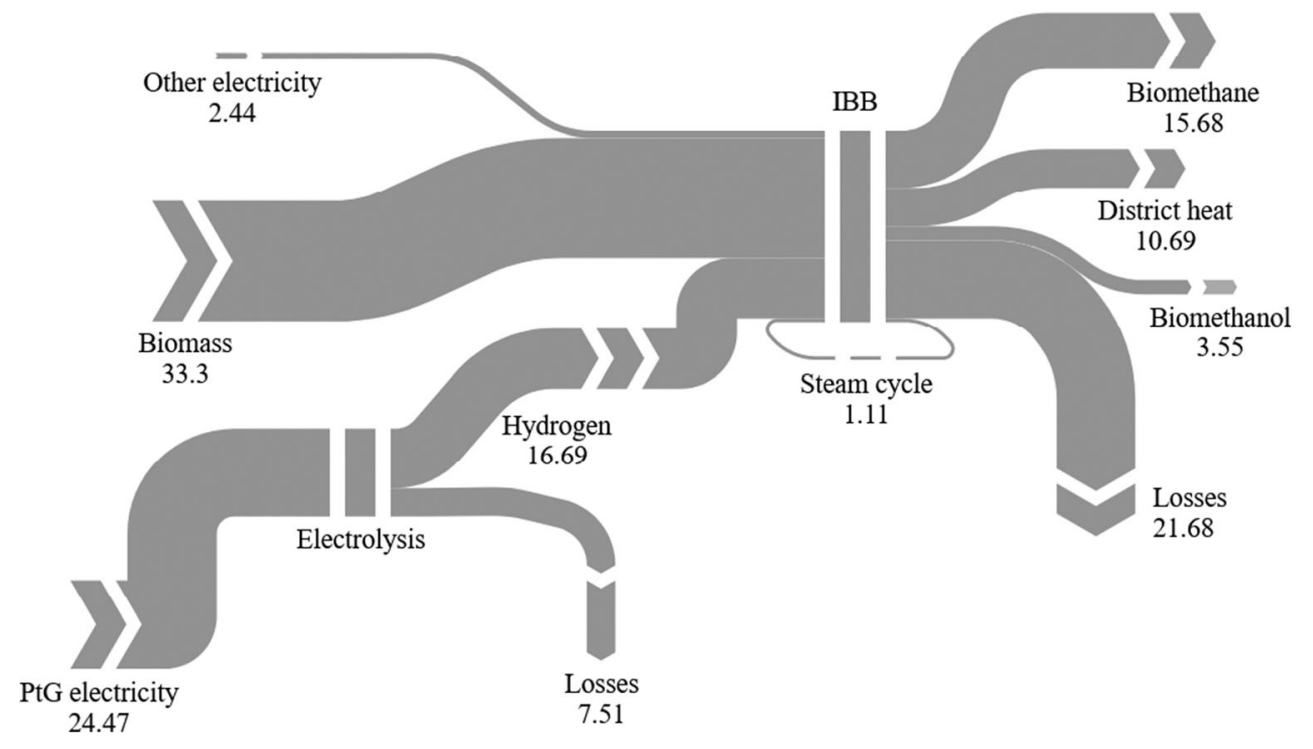


Table 13 Summary of project economic indicators

\begin{tabular}{lllll}
\hline Process ID & $\begin{array}{l}\text { PEC } \\
\text { M€ }\end{array}$ & TCI & $\begin{array}{l}\text { D-OPEX } \\
\text { M€/year }\end{array}$ & T-OPEX \\
\hline SAB & 32.3 & 125.5 & 9.8 & 16.2 \\
IBB & 45.1 & 152.4 & 15.7 & 25.1 \\
\hline
\end{tabular}

\subsection{Minimum selling price variation}

As displayed by Table 14, the SAB process can produce biomethane at a MSP of $2.38 € / \mathrm{Nm}^{3}$, which is $11 \%$ lower than we previously estimated for a gasification-electrolysisbiomethanation process with catalytic water-gas shift [11] at an IRR of 7\% (10\% in this study), and approximately $170 \%$ higher than estimated by Michailos et al. [10] for a process without electrolysis. The lower MSP is made possible by a yearly side revenue of 3.9 M€ earned from district heat exports. However, despite having a positive effect on compression energy consumption, as described above, the absence of WGS needs compensation by means of high hydrogen flow rates and has thus a strong impact on MSP.

By selling renewable biomethanol to generate a further side revenue stream, the IBB process can deliver a biomethane MSP of $3.28 € / \mathrm{Nm}^{3}$, which corresponds to a $38 \%$ increase over the standalone process (SAB), indicating that the additional capital and operating costs generated by catalytic methanol synthesis and large-scale (24 MW) electrolysis outweigh the additional revenue earned at the current methanol selling price $(275 € / t)$. It is possible to hypothesize that in future energy markets, a credit will be paid on any marginal renewable carbon that can be converted to fuel and stored in the short term, as is assumed in the two scenarios $\operatorname{IBB}(C C(25))$ and $\operatorname{IBB}(C C(50))$ in Table 14. However, the variation in bSNG selling price is negligible $(-1 \%)$ even in the presence of carbon credits on the renewable carbon stored as methanol, paid at a price equivalent to $25 € / t_{\mathrm{CO} 2}$ (IBB(CC25), which is close to the trading average in the European Emission Trading Scheme (ETS) [80]. The linear effect of carbon price on bSNG MSP is very limited (slope, $0.04 \mathrm{c} € \cdot \mathrm{t}_{\mathrm{CO} 2} / \mathrm{Nm}^{3} / €$ ), and even at a carbon price of $50 € / t_{\mathrm{CO} 2}$ (IBB(CC50)), the MSP only decreases by approximately $1 \%\left(3.26 € / \mathrm{Nm}^{3}\right)$. In fact, the theoretical carbon credit prices that would generate an MSP equal to the natural gas consumer price in Europe $(0.5 € / \mathrm{Nm} 3$, Table 15), or the MSP of bSNG in the SAB process (2.38 $\left.€ / \mathrm{Nm}^{3}\right)$, were calculated at extreme rates of $5297 € / t_{\mathrm{CO} 2}$ and $1718 € / \mathrm{t}_{\mathrm{CO} 2}$, respectively, under the conditions considered. This demonstrates that, for the process analyzed, carbon utilization requires substantially larger $\mathrm{CO}_{2}$ flows in order to have any meaningful impacts on process economics. As a result of the process economic indicators estimated, the MSP of standalone bSNG (SAB) is still $230 \%$ higher than the subsidized price of biomethane from anaerobic digestion of waste in Italy, granted by the application of the EU Renewable Energy Directive (RED 2009/28/EC) (Table 15).

\subsection{Price gap of bSGN in biomass-to-biomethane processes}

Figure 12 and 13 display the results of a sensitivity analysis on the cost of grid gas renewability by showing the monetary value of the government subsidy that would be required to match the bSNG price gap under parameter variation.

As expected from the breakdown of direct OPEX, the price gap is largely influenced by the variation in surplus energy cost and biomass cost (Fig. 12). The highest $\mathrm{C}_{\text {biom }}\left(200 € / \mathrm{t}_{\text {dry }}\right.$, $+100 \%$ on base case $)$ and the highest $\mathrm{C}_{\mathrm{PtG}}(0.11 € / \mathrm{kWh},+$ $200 \%$ on base case) generate a $44 \%$ increase in MSP. However, in the case of zero-cost biomass, as in the hypothesis of waste lignocellulosic biomass, and zero-cost surplus energy, under the hypothesis of an energy system with a very high electrification level, the required subsidy would be 0.13 $€ / \mathrm{kWh}_{\mathrm{bSNG}}$, which is $550 \%$ higher than the current market
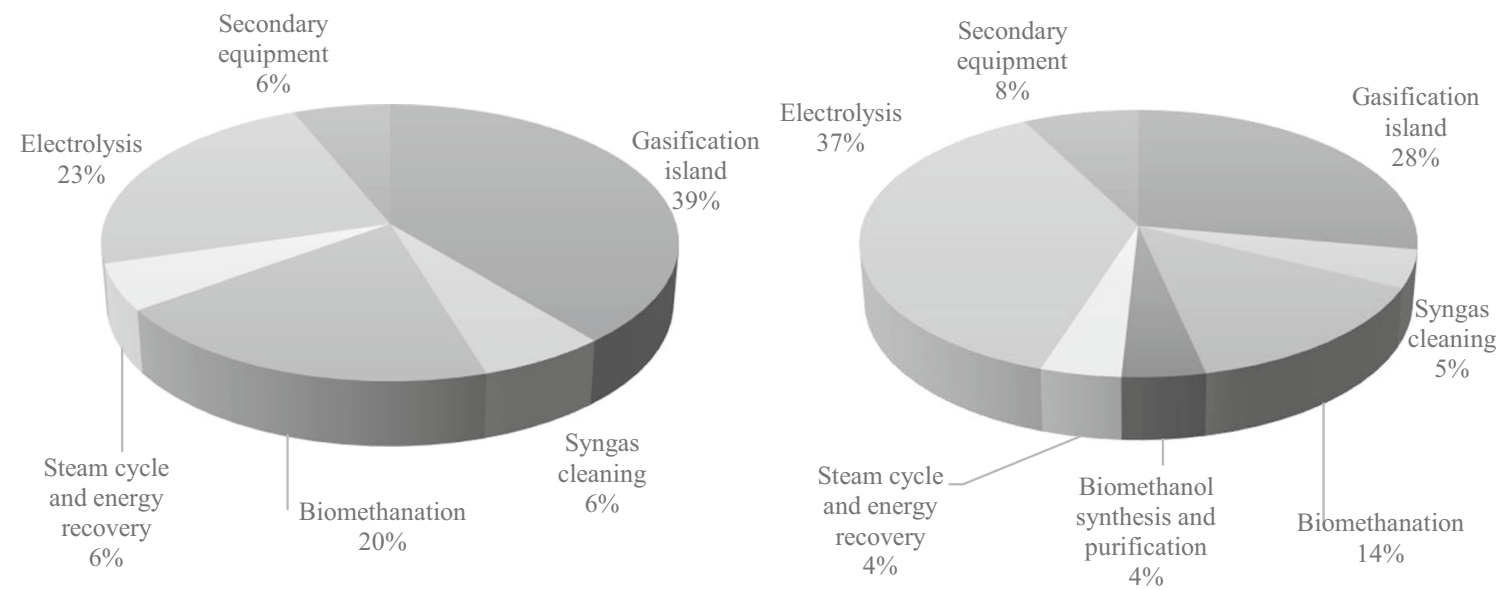

Fig. 10 Breakdown of purchased equipment cost (PEC) for the SAB (left) and the IBB (right) processes 

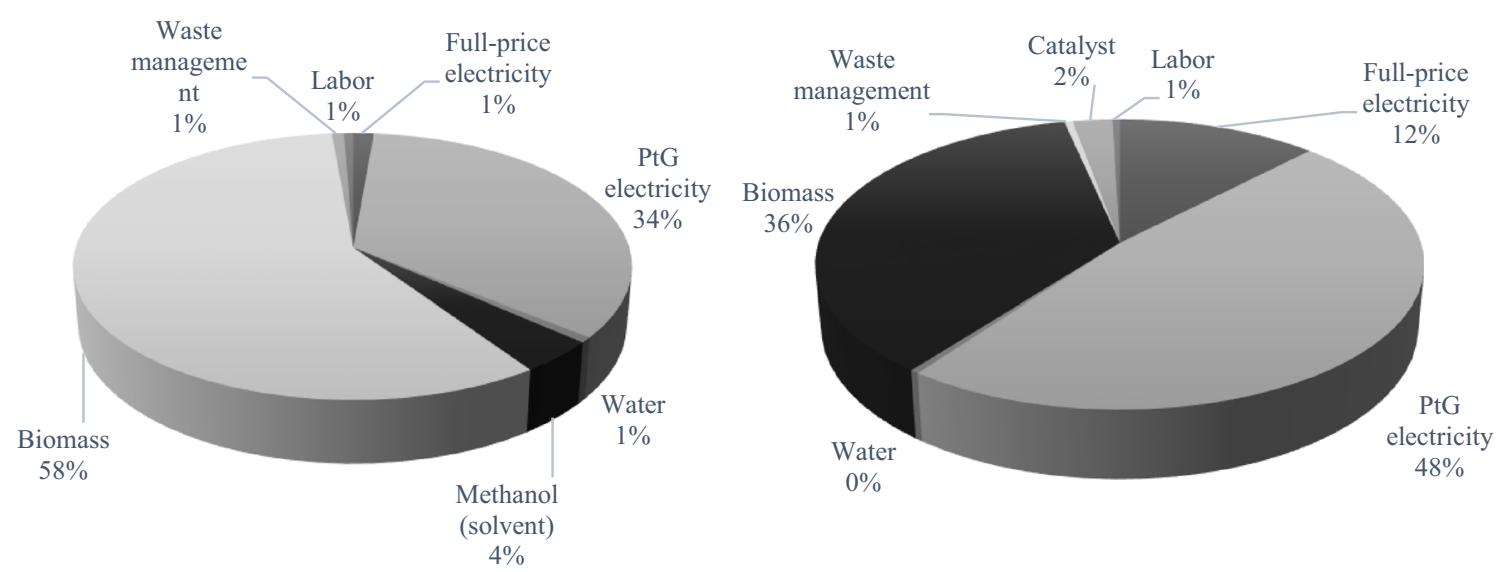

Fig. 11 Direct operating cost breakdown for the SAB (left) and the IBB (right) processes

price gap of both biomethane from AD (approximately 0.04 $€ / \mathrm{kWh})$. This indicates that subsidizing biomass-tobiomethane plants through the existing decarbonization financial support would be insufficient under any currently plausible techno-economic assumptions. The strategic nature of decentralized bSNG production along with its energy storage role would need to be factored into local energy policies to support biomass-to-biomethane developments through higher fiscal incentives in the future. The price gap achievable through integrated carbon utilization and biomethanol synthesis (IBB, Fig. 13) is higher than in SAB, although it is little influenced by biomethanol selling prices, demonstrating that the feasibility of such integrated biomethane-biomethanol process is ultimately cost-constrained, due to the CAPEX and OPEX intensity of electrolytic hydrogen. In fact, only a $38 \%$ increase in bSNG MSP is observed for $P_{b M e O H}=0$ ($100 \%)$ when $C_{P t G}=0.11 € / \mathrm{kWh}(+200 \%)$. Consequently, the bSNG price gap under the best-case assumptions for the cost
Table 14 Summary of main economic streams and bSNG minimum selling price for the two processes

\begin{tabular}{|c|c|c|c|c|c|c|c|}
\hline \multirow[t]{2}{*}{ Process ID } & \multirow{2}{*}{$\begin{array}{l}\mathrm{ACC} \\
€ / \text { year }\end{array}$} & \multirow[t]{2}{*}{ OPEX } & \multicolumn{4}{|c|}{ Side Revenues } & \multirow{2}{*}{$\begin{array}{l}\text { bSNG } \\
\mathrm{MSP} \\
€ / \mathrm{Nm}^{3}{ }_{\mathrm{bSNG}}\end{array}$} \\
\hline & & & $\begin{array}{l}\text { District } \\
\text { Heat }\end{array}$ & $\mathrm{bMeOH}$ & $\begin{array}{l}\text { Carbon } \\
\text { credits }\end{array}$ & Total & \\
\hline SAB & $15,362,766$ & $16,222,193$ & $3,875,977$ & & & $3,875,977$ & 2.38 \\
\hline IBB & $18,668,414$ & $25,128,247$ & $6,555,056$ & $1,035,689$ & & $7,590,745$ & 3.28 \\
\hline $\mathrm{IBB}(\mathrm{CC} 25)$ & $18,668,414$ & $25,128,247$ & $6,555,056$ & $1,035,689$ & 182,032 & $7,772,778$ & 3.27 \\
\hline $\mathrm{IBB}(\mathrm{CC} 50)$ & $18,668,414$ & $25,128,247$ & $6,555,056$ & $1,035,689$ & 364,065 & $7,954,810$ & 3.26 \\
\hline
\end{tabular}

Table 15 Summary of price comparisons between bSNG from SAB and biomethane from AD

\begin{tabular}{|c|c|c|c|}
\hline Product type & Description & $\begin{array}{l}\text { Price on product basis } \\
€ / \mathrm{Nm}^{3}\end{array}$ & $\begin{array}{l}\text { Price on energy basis } \\
€ / \mathrm{kWh}\end{array}$ \\
\hline bSNG from $\mathrm{SAB}$ & SAB process in this study & 2.38 & 0.22 \\
\hline $\begin{array}{l}\text { Biomethane from } \mathrm{AD} \text { of waste } \\
\text { and by-products }\end{array}$ & $\begin{array}{l}\text { Anaerobic digestion of waste and by-products } \\
\text { with biogas upgrading }\end{array}$ & $0.72^{\mathrm{b}}$ & $0.07^{\mathrm{c}}$ \\
\hline European natural gas & Grid natural gas for non-household consumers in EU28 & - & 0.03 \\
\hline Incentive required & Price gap between bSNG (SAB process) and natural gas & 1.88 & 0.17 \\
\hline
\end{tabular}

${ }^{a}$ Inclusive of average natural gas wholesale market price and advanced biofuel incentive (64.5 €/MWh)

${ }^{\mathrm{b}}$ Based on a 3-month average wholesale market price of $0.01 € / \mathrm{kWh}$, January-March 2020 [81]

${ }^{\mathrm{c}}$ Based on a biomethane LHV of $10.9 \mathrm{kWh} / \mathrm{Nm}^{3}$ 


\section{bSNG market price gap $\left(€ / \mathrm{kWh}_{\mathrm{LHV}}\right)$ \\ $\square 0.10-0.15 \quad \square 0.15-0.20 \quad \square 0.20-0.25 \quad \square 0.25-0.30$}

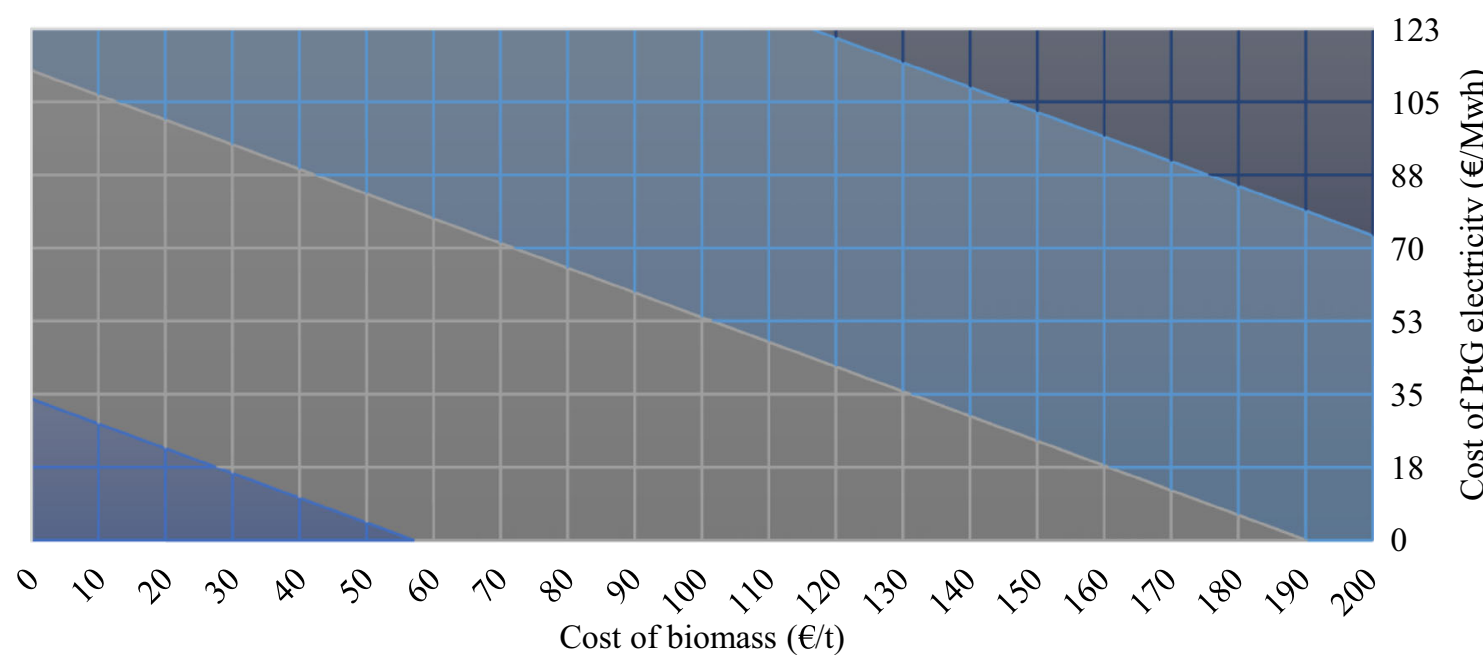

Fig. 12 Variation in the cost of gas grid renewability for the SAB process under varying biomass and PtG electricity costs

of energy $\left(C_{P t G}=0(-100 \%\right.$ on base case $\left.)\right)$ and for the price of biomethanol $\left(P_{b M e O H}=500 € / \mathrm{t}(+100 \%\right.$ on base case $\left.)\right)$ is $0.25 € / \mathrm{kWh}_{\mathrm{bSNG}}$. This indicates that, compared to SAB, carbon utilization for methanol synthesis would require an even larger fiscal support to reach financial competitiveness. Therefore, greater subsidization would be required in an IBB scenario, where a premium price would be needed in order sustain the role of biomethanol in enabling the development of localized biochemical value chains.

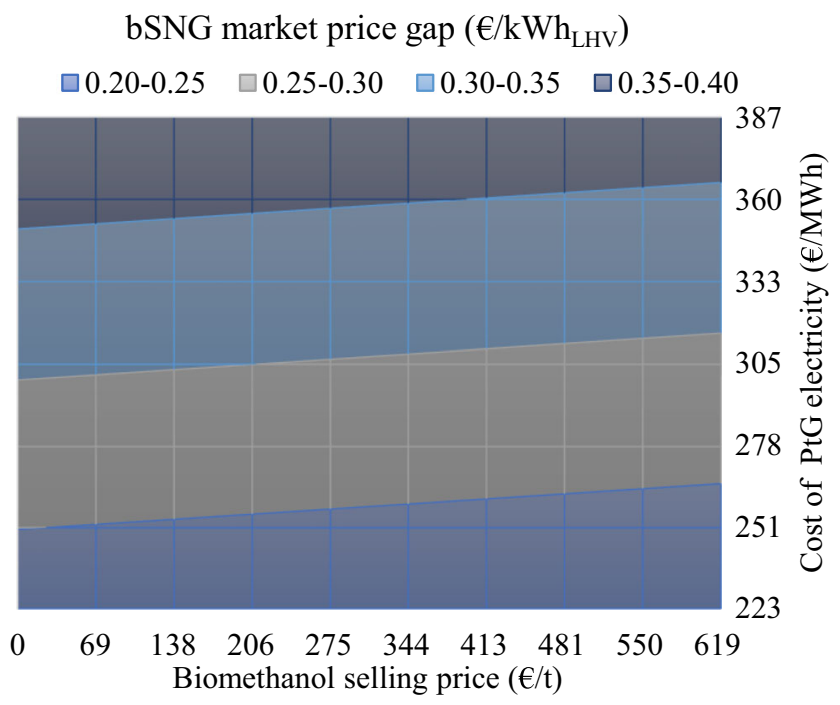

Fig. 13 Variation in the cost of gas grid renewability for the IBB process under varying biomethanol selling prices and $\mathrm{PtG}$ electricity costs at a constant biomass cost of $100 € / t_{\text {dry }}$

\subsection{Plant size competitiveness}

The supply-side competitiveness of the biorenewable commodities considered (bSNG and $\mathrm{bMeOH}$ ) is also affected by the production capacities achievable by the two processes in comparison with existing commercial processes in Europe (Table 16). Both processes analyzed can deliver approximately three times the bSNG capacity of a typical anaerobic digestion plant currently in operation or under construction in Europe (500 $\mathrm{Nm}^{3} / \mathrm{h}$ ). The IBB process can deliver additional $11 \mathrm{t} \mathrm{bMeOH} /$ day, equivalent to the production capacity of the George Olah pilot plant, which corresponds to approximately $0.2 \%$ of the capacity of an average European plant producing methanol from natural gas. With its current output, the George Olah plant is expected to satisfy approximately about $2.5 \%$ of the total gasoline market in Iceland [86], indicating that this scale would be appropriate for the supply of renewable methanol as fuel or as chemical feedstock in decentralized supply chains.

\section{Conclusions}

In this study, we carried out the techno-economic modeling of two processes comprising integrated biomass gasification, electrolysis, and syngas biomethanation (IBGEB) with combined heat and power recovery. The first process operates standalone biomethanation of syngas with the aid of water electrolysis and can produce approximately $38,000 \mathrm{Nm}^{3}$ of bSNG per day, with a total plant efficiency of $50.6 \%$. The second process (integrated biomethane-biomethanol, IBB) exploits the unconverted carbon stream from the biomethanation 
Table 16 Summary of typical plant sizes per type of product

\begin{tabular}{llll}
\hline Product type & Production process & Production capacity & Reference \\
\hline Biomethane & Anaerobic digestion of waste & $500 \mathrm{Nm}^{3} / \mathrm{h}$ & $11 \mathrm{t} /$ day \\
Biomethanol & Catalytic $\mathrm{CO}_{2}$ hydrogenation $($ George Olah pilot plant) & $1 \mathrm{t} /$ day & {$[82]$} \\
& Catalytic $\mathrm{CO}_{2}$ hydrogenation $\left(\mathrm{MefCO}_{2}\right.$ pilot plant $)$ & $5000 \mathrm{t} /$ day & {$[83]$} \\
Fossil-based methanol & Steam reforming of natural gas and syngas hydrogenation & {$[84]$} & {$[85]$} \\
\hline
\end{tabular}

process to recover energy and synthesize methanol via direct catalytic $\mathrm{CO}_{2}$ hydrogenation. In addition to the same bSNG output, the IBB process can produce $11 \mathrm{t}$ /day of biomethanol, at a $99 \%$ purity. The selection of low-pressure liquid scrubbing processes in syngas conditioning upstream of biomethanation brings energy efficiency benefits compared to a catalytic WGS train, delivering a $64 \%$ decrease in specific energy consumption per bSNG unit volume, if electrolysis is neglected. The MSP of bSNG in the SAB process is 2.38 $€ / \mathrm{Nm}^{3}$, which is more than three times the magnitude of the subsidized price currently paid to biomethane from anaerobic digestion under the RED in Italy. The integrated production of biomethanol shows little global energy efficiency gains in comparison with SAB (51.7\%) due to the large increase in electrolytic hydrogen demand, but it shows a substantial improvement of biomass-to-fuel carbon efficiency (33 vs. 26\%). The integration of biomethanol production into the process generates high additional capital and operating costs, mainly due to the large additional electrolysis size required. As a result, the IBB process brings an increase in bSNG MSP of $76 \%$, even with carbon credits on the additional carbon stored as fuel and does not improve bSNG feasibility in the absence of very intensive subsidization. The levels of subsidization required for the two processes exceed $0.13 € / \mathrm{kWh}_{\mathrm{bSNG}}$ for $\mathrm{SAB}$ and $0.25 € / \mathrm{kWh}_{\mathrm{bSNG}}$ for IBB under the most optimistic OPEX assumptions and suggest that government support for the strategic nature of these biorenewable commodities would be needed to complement existing decarbonization financial incentives. Despite its limited economic competitiveness, the IBB process would be competitive with existing renewable gas production plants, in terms of bSNG production capacity and could be adequate in supplying methanol to a decentralized biorenewable supply chain.

Supplementary Information The online version contains supplementary material available at https://doi.org/10.1007/s13399-020-01178-y.

Funding Open Access funding provided by Libera Università di Bolzano within the CRUI-CARE Agreement.

Open Access This article is licensed under a Creative Commons Attribution 4.0 International License, which permits use, sharing, adaptation, distribution and reproduction in any medium or format, as long as you give appropriate credit to the original author(s) and the source, provide a link to the Creative Commons licence, and indicate if changes were made. The images or other third party material in this article are included in the article's Creative Commons licence, unless indicated otherwise in a credit line to the material. If material is not included in the article's Creative Commons licence and your intended use is not permitted by statutory regulation or exceeds the permitted use, you will need to obtain permission directly from the copyright holder. To view a copy of this licence, visit http://creativecommons.org/licenses/by/4.0/.

\section{References}

1. Rauch R, Hrbek J, Hofbauer H (2015) Biomass gasification for synthesis gas production and applications of the syngas. Adv Bioenergy Sustain Chall 73-91. https://doi.org/10.1002/ 9781118957844.ch7

2. Ptasinski KJ (2015) Bioenergy systems. Effic. Biomass Energy

3. Rönsch S, Schneider J, Matthischke S et al (2016) Review on methanation - from fundamentals to current projects. Fuel 166: 276-296. https://doi.org/10.1016/J.FUEL.2015.10.111

4. IEA (2017) World Energy Outlook 2017

5. Wulf C, Linßen J, Zapp P (2018) Review of power-to-gas projects in Europe. Energy Procedia 155:367-378. https://doi.org/10.1016/ j.egypro.2018.11.041

6. Karl J, Neubert M (2017) Production of substitute natural gas: thermochemical methods

7. Grimalt-Alemany A, Skiadas IV, Gavala HN (2018) Syngas biomethanation: state-of-the-art review and perspectives. Biofuels Bioprod Biorefin 12:139-158. https://doi.org/10.1002/bbb.1826

8. Lehner M, Tichler R, Steinmüller H, Koppe M (2014) The powerto-gas concept. In: Power-to-Gas: Technology and Business Models. Springer International Publishing, Cham, pp 7-17

9. Lehner M, Tichler R, Steinmüller H, Koppe M (2014) Methanation. In: Power-to-Gas: Technology and Business Models. Springer International Publishing, Cham, pp 41-61

10. Michailos S, Emenike O, Ingham D et al (2019) Methane production via syngas fermentation within the bio-CCS concept: a technoeconomic assessment. Biochem Eng J 150:107290. https://doi.org/ 10.1016/j.bej.2019.107290

11. Menin L, Vakalis S, Benedetti V et al (2020) Techno-economic assessment of an integrated biomass gasification, electrolysis, and syngas biomethanation process. Biomass Convers Biorefinery. https://doi.org/10.1007/s13399-020-00654-9

12. Michailos S, Walker M, Moody A et al (2020) Biomethane production using an integrated anaerobic digestion, gasification and $\mathrm{CO} 2$ biomethanation process in a real waste water treatment plant: a techno-economic assessment. Energy Convers Manag 209: 112663. https://doi.org/10.1016/j.enconman.2020.112663

13. Olah GA, Goeppert A, Prakash GKS (2009) Methanol-based chemicals, synthetic hydrocarbons and materials. In: Beyond Oil and Gas: The Methanol Economy. John Wiley \& Sons, Ltd, pp 279-288

14. Olah GA, Goeppert A, Prakash GKS (2009) Methanol and dimeth$\mathrm{yl}$ ether as fuels and energy carriers. In: Beyond Oil and Gas: The 
Methanol Economy. Wiley-VCH Verlag GmbH \& Co. KGaA, Weinheim, pp 185-231

15. Wang SW, Li DX, Ruan WB et al (2018) A techno-economic review of biomass gasification for production of chemicals. Energy Sources, Part B Econ Plan Policy 13:351-356. https://doi. org/10.1080/15567249.2017.1349212

16. Simakov DSA (2017) Thermocatalytic conversion of CO2. In: In: Renewable Synthetic Fuels and Chemicals from Carbon Dioxide: Fundamentals, Catalysis, Design Considerations and Technological Challenges. Springer International Publishing, Cham, pp 1-25

17. Anwar MN, Fayyaz A, Sohail NF et al (2020) CO2 utilization: turning greenhouse gas into fuels and valuable products. J Environ Manag 260:110059. https://doi.org/10.1016/j.jenvman. 2019.110059

18. Bos MJ, Kersten SRA, Brilman DWF (2020) Wind power to methanol: renewable methanol production using electricity, electrolysis of water and CO2 air capture. Appl Energy 264:114672. https://doi. org/10.1016/j.apenergy.2020.114672

19. Rabaçal M, Ferreira AF, Silva CAM, Editors MC (2017) Biorefineries targeting energy, high value products and waste valorisation. Lect Notes Energy 57:307. https://doi.org/10.1007/ 978-3-319-48288-0

20. Araya SS, Liso V, Cui X et al (2020) A review of the methanol economy: the fuel cell route. Energies 13:596. https://doi.org/10. 3390/en13030596

21. Moioli E, Mutschler R, Züttel A (2019) Renewable energy storage via $\mathrm{CO} 2$ and $\mathrm{H} 2$ conversion to methane and methanol: assessment for small scale applications. Renew Sust Energ Rev 107:497-506. https://doi.org/10.1016/j.rser.2019.03.022

22. Porté H, Kougias PG, Alfaro N et al (2019) Process performance and microbial community structure in thermophilic trickling biofilter reactors for biogas upgrading. Sci Total Environ 655: 529-538. https://doi.org/10.1016/j.scitotenv.2018.11.289

23. Rachbauer L, Voitl G, Bochmann G, Fuchs W (2016) Biological biogas upgrading capacity of a hydrogenotrophic community in a trickle-bed reactor. Appl Energy 180:483-490. https://doi.org/10. 1016/j.apenergy.2016.07.109

24. Bassani I, Kougias PG, Treu L et al (2017) Optimization of hydrogen dispersion in thermophilic up-flow reactors for ex situ biogas upgrading. Bioresour Technol 234:310-319. https://doi.org/10. 1016/j.biortech.2017.03.055

25. Thema M, Bauer F, Sterner M (2019) Power-to-gas: electrolysis and methanation status review. Renew Sust Energ Rev 112:775787. https://doi.org/10.1016/j.rser.2019.06.030

26. Vo TTQ, Wall DM, Ring D et al (2018) Techno-economic analysis of biogas upgrading via amine scrubber, carbon capture and ex-situ methanation. Appl Energy 212:1191-1202. https://doi.org/10. 1016/j.apenergy.2017.12.099

27. Kassem N, Hockey J, Lopez C et al (2020) Integrating anaerobic digestion, hydrothermal liquefaction, and biomethanation within a power-to-gas framework for dairy waste management and grid decarbonization: a techno-economic assessment. Sustain Energy Fuels 4:4644-4661. https://doi.org/10.1039/d0se00608d

28. Asimakopoulos K, Gavala HN, Skiadas IV (2019) Biomethanation of syngas by enriched mixed anaerobic consortia in trickle bed reactors. Waste Biomass Valoriz 11:495-512. 0:0. https://doi.org/ 10.1007/s12649-019-00649-2

29. Haro P, Johnsson F, Thunman H (2016) Improved syngas processing for enhanced Bio-SNG production: a techno-economic assessment. Energy 101:380-389. https://doi.org/10.1016/j.energy.2016. 02.037

30. Alamia A, Larsson A, Breitholtz C, Thunman H (2017) Performance of large-scale biomass gasifiers in a biorefinery, a state-of-the-art reference. Int J Energy Res 41:2001-2019. https:// doi.org/10.1002/er.3758
31. Yun HAH, Ramírez-Solís S, Dupont V (2020) Bio-CH4 from palm empty fruit bunch via pyrolysis-direct methanation: full plant model and experiments with bio-oil surrogate. J Clean Prod 244:118737. https://doi.org/10.1016/j.jclepro.2019.118737

32. Guiot SR, Cimpoia R, Carayon G (2011) Potential of wastewatertreating anaerobic granules for biomethanation of synthesis gas. Environ Sci Technol 45:2006-2012. https://doi.org/10.1021/ es $102728 \mathrm{~m}$

33. François J, Mauviel G, Feidt M et al (2013) Modeling of a biomass gasification CHP plant: influence of various parameters on energetic and exergetic efficiencies. Energy Fuel 27:7398-7412. https:// doi.org/10.1021/ef4011466

34. Alamia A, Thunman H, Seemann M (2016) Process simulation of dual fluidized bed gasifiers using experimental data. Energy Fuel 30:4017-4033. https://doi.org/10.1021/acs.energyfuels.6b00122

35. Duret A, Friedli C, Maréchal F (2005) Process design of Synthetic Natural Gas (SNG) production using wood gasification. J Clean Prod 13:1434-1446. https://doi.org/10.1016/j.jclepro.2005.04.009

36. Li XT, Grace JR, Lim CJ et al (2004) Biomass gasification in a circulating fluidized bed. Biomass Bioenergy 26:171-193. https:// doi.org/10.1016/S0961-9534(03)00084-9

37. Francois J, Abdelouahed L, Mauviel G et al (2013) Detailed process modeling of a wood gasification combined heat and power plant. Biomass Bioenergy 51:68-82. https://doi.org/10.1016/j.biombioe. 2013.01.004

38. Abdelouahed L, Authier O, Mauviel G et al (2012) Detailed modeling of biomass gasification in dual fluidized bed reactors under aspen plus. Energy Fuel 26:3840-3855. https://doi.org/10.1021/ ef300411k

39. Zhang Z, Pang S (2019) Experimental investigation of tar formation and producer gas composition in biomass steam gasification in a $100 \mathrm{~kW}$ dual fluidised bed gasifier. Renew Energy 132:416-424. https://doi.org/10.1016/j.renene.2018.07.144

40. Karl J, Pröll T (2018) Steam gasification of biomass in dual fluidized bed gasifiers: a review. Renew Sust Energ Rev 98:64-78. https://doi.org/10.1016/j.rser.2018.09.010

41. Gatti M, Martelli E, Marechal F, Consonni S (2014) Review, modeling, heat integration, and improved schemes of Rectisol@based processes for CO2 capture. Appl Therm Eng 70:1123-1140. https://doi.org/10.1016/j.applthermaleng.2014.05.001

42. Schefflan R (2011) Teach yourself the basics of Aspen Plus

43. (2000) Aspen Plus ${ }^{\circledR}$ User Guide. 936

44. Magli F, Capra F, Gatti M, Martelli E (2018) Process selection, modelling and optimization of a water scrubbing process for energy-self-sufficient biogas upgrading plants. Sustain Energy Technol Assessments 27:63-73. https://doi.org/10.1016/j.seta. 2018.02.001

45. Asimakopoulos K, Łężyk M, Grimalt-Alemany A et al (2020) Temperature effects on syngas biomethanation performed in a trickle bed reactor. Chem Eng J 393:124739. https://doi.org/10.1016/j. cej.2020.124739

46. Ullrich T, Lindner J, Bär K et al (2018) Influence of operating pressure on the biological hydrogen methanation in trickle-bed reactors. Bioresour Technol 247:7-13. https://doi.org/10.1016/j. biortech.2017.09.069

47. Anicic B, Trop P, Goricanec D (2014) Comparison between two methods of methanol production fromcarbon dioxide. Energy 77: 279-289. https://doi.org/10.1016/j.energy.2014.09.069

48. Gallucci F, Paturzo L, Basile A (2004) An experimental study of $\mathrm{CO} 2$ hydrogenation into methanol involving a zeolite membrane reactor. Chem Eng Process Process Intensif 43:1029-1036. https:// doi.org/10.1016/j.cep.2003.10.005

49. Elkamel A, Reza Zahedi G, Marton C, Lohi A (2009) Optimal fixed bed reactor network configuration for the efficient recycling of $\mathrm{CO} 2$ into methanol. Energies 2:180-189. https://doi.org/10.3390/ en20200180 
50. Centi G, Perathoner S (2009) Opportunities and prospects in the chemical recycling of carbon dioxide to fuels. Catal Today 148: 191-205. https://doi.org/10.1016/j.cattod.2009.07.075

51. Van-Dal ÉS, Bouallou C (2013) Design and simulation of a methanol production plant from $\mathrm{CO} 2$ hydrogenation. J Clean Prod 57: 38-45. https://doi.org/10.1016/j.jclepro.2013.06.008

52. Crivellari A, Cozzani V, Dincer I (2019) Exergetic and exergoeconomic analyses of novel methanol synthesis processes driven by offshore renewable energies. Energy 187:115947. https://doi.org/10.1016/j.energy.2019.115947

53. Matzen M, Alhajji M, Demirel Y (2015) Chemical storage of wind energy by renewable methanol production: feasibility analysis using a multi-criteria decision matrix. Energy 93:343-353. https:// doi.org/10.1016/j.energy.2015.09.043

54. Rahmatmand B, Rahimpour MR, Keshavarz P (2019) Introducing a novel process to enhance the syngas conversion to methanol over $\mathrm{Cu} / \mathrm{ZnO} / \mathrm{A} 12 \mathrm{O} 3$ catalyst. Fuel Process Technol 193:159-179. https://doi.org/10.1016/j.fuproc.2019.05.014

55. Lee A (2020) Japan completes construction of world's largest green hydrogen project. In: Institutre Energy Econ. Financ. Anal. https:// ieefa.org/japan-completes-construction-of-worlds-largest-greenhydrogen-project/

56. (2018) Construction begins on Fukushima Hydrogen Energy Research Field. Fuel Cells Bull 2018:9. https://doi.org/10.1016/ S1464-2859(18)30332-8

57. Guillet N, Millet P (2015) Alkaline water electrolysis. In: Hydrogen Production. John Wiley \& Sons, Ltd, pp 117-166

58. Schalenbach M, Zeradjanin AR, Kasian O et al (2018) A perspective on low-temperature water electrolysis - challenges in alkaline and acidic technology. Int J Electrochem Sci 13:1173-1226. https:// doi.org/10.20964/2018.02.26

59. Ayers K, Danilovic N, Ouimet R et al (2019) Perspectives on lowtemperature electrolysis and potential for renewable hydrogen at scale. Annu Rev Chem Biomol Eng 10:219-239. https://oi.org/ 10.1146/annurev-chembioeng-060718-030241

60. Holmgren KM (2015) Investment cost estimates for gasificationbased biofuel production systems

61. Karimi M, Hillestad M, Svendsen HF (2011) Capital costs and energy considerations of different alternative stripper configurations for post combustion $\mathrm{CO} 2$ capture. Chem Eng Res Des 89: 1229-1236. https://doi.org/10.1016/j.cherd.2011.03.005

62. Liu X, Yang S, Hu Z, Qian Y (2015) Simulation and assessment of an integrated acid gas removal process with higher $\mathrm{CO} 2$ capture rate. Comput Chem Eng 83:48-57. https://doi.org/10.1016/j. compchemeng.2015.01.008

63. Ferella F, Cucchiella F, D'Adamo I, Gallucci K (2019) A technoeconomic assessment of biogas upgrading in a developed market. J Clean Prod 210:945-957. https://doi.org/10.1016/j.jclepro.2018. 11.073

64. Albrecht FG, König DH, Baucks N, Dietrich R-UU (2017) A standardized methodology for the techno-economic evaluation of alternative fuels - a case study. Fuel 194:511-526. https://doi.org/10. 1016/j.fuel.2016.12.003

65. Brown RC, Brown TR (2014) Economics of biorenewable resources. In: Biorenewable Resources. John Wiley \& Sons, Ltd, pp 287-326

66. Methanex Corporation (2020) Pricing. https://www.methanex.com/ our-business/pricing. Accessed 8 Oct 2020

67. Gruppo Hera (2020) Prezzi del servizio teleriscaldamento. https:// www.gruppohera.it/binary/hr_clienti/casa_teleriscaldamento tariffe_feb15/2020_Bologna_Modulo_TARIFFE_01_07_2020. 1596527623.pdf. Accessed 12 Oct 2020

68. Alperia (2020) La nostra offerta in dettaglio. https://www.alperia. eu/la-mia-casa/telecalore/calore-bolzano.html. Accessed 12 Oct 2020
69. a2a (2020) Prezzi fornitura teleriscaldamento, Bergamo e Milano. https:/www.a2acaloreservizi.eu/home/cms/a2a_caloreservizi/ area_clienti/documenti/Prezzi-TLR-MILANO-BERGAMO-01 ott_2020.pdf. Accessed 12 Oct 2020

70. Eurostat (2020) Gas prices for non-household consumers - bi-annual data (from 2007 onwards). https://appsso.eurostat.ec.europa. eu/nui/show.do?dataset=nrg_pc_203\&lang=en. Accessed 8 Apr 2020

71. Alsayegh S, Johnson JR, Ohs B, Wessling M (2019) Methanol production via direct carbon dioxide hydrogenation using hydrogen from photocatalytic water splitting: process development and techno-economic analysis. J Clean Prod 208:1446-1458. https:// doi.org/10.1016/j.jclepro.2018.10.132

72. Pérez-Fortes M, Schöneberger JC, Boulamanti A, Tzimas E (2016) Methanol synthesis using captured $\mathrm{CO} 2$ as raw material: technoeconomic and environmental assessment. Appl Energy 161:718 732. https://doi.org/10.1016/j.apenergy.2015.07.067

73. Guiot S (2013) Bio-upgrading of syngas into methane. In: In: Proceedings of the 13th World Congress on Anaerobic Digestion. Santiago de Compostela, Spain

74. Chauvy R, Dubois L, Lybaert P et al (2020) Production of synthetic natural gas from industrial carbon dioxide. Appl Energy 260: 114249. https://doi.org/10.1016/j.apenergy.2019.114249

75. Peters R, Baltruweit M, Grube T et al (2019) A techno economic analysis of the power to gas route. J CO2 Util 34:616-634. https:// doi.org/10.1016/j.jcou.2019.07.009

76. Adnan MA, Kibria MG (2020) Comparative techno-economic and life-cycle assessment of power-to-methanol synthesis pathways. Appl Energy 278:115614. https://doi.org/10.1016/j.apenergy. 2020.115614

77. Nyári J, Magdeldin M, Larmi M et al (2020) Techno-economic barriers of an industrial-scale methanol CCU-plant. J CO2 Util 39:101166. https://doi.org/10.1016/j.jcou.2020.101166

78. Michailos S, McCord S, Sick V et al (2019) Dimethyl ether synthesis via captured $\mathrm{CO} 2$ hydrogenation within the power to liquids concept: a techno-economic assessment. Energy Convers Manag 184:262-276. https://doi.org/10.1016/j.enconman.2019.01.046

79. Brynolf S, Taljegard M, Grahn M, Hansson J (2018) Electrofuels for the transport sector: a review of production costs. Renew Sust Energ Rev 81:1887-1905

80. Bloomberg (2020) ECX emissions (ICE). https://www.bloomberg. com/quote/MO1:COM. Accessed Apr 2020

81. GME (2020) Statistiche - comunicazioni DM 2.03.2018 biometano. https://www.mercatoelettrico.org/It/Statistiche/Gas/ ComBiometanoNew.aspx. Accessed 9 Apr 2020

82. Scarlat N, Dallemand JF, Fahl F (2018) Biogas: developments and perspectives in Europe. Renew Energy 129:457-472. https://doi. org/10.1016/j.renene.2018.03.006

83. Hobson C, Marquez C (2018) Renewable methanol report. Accessed Apr 2020

84. MefCO2 (2019) Project progress. http://www.mefco2.eu/project progress.php. Accessed Apr 2020

85. Fraile D, Lanoix J-C, Maio P, et al (2015) Overview of the market segmentation for hydrogen across potential customer groups, based on key application areas

86. chemicals-technology.com (2012) George Olah CO2 to renewable methanol plant, Reykjanes. In: Verdict Media Ltd. https://www. chemicals-technology.com/projects/george-olah-renewablemethanol-plant-iceland/. Accessed Apr 2020

Publisher's Note Springer Nature remains neutral with regard to jurisdictional claims in published maps and institutional affiliations. 